\title{
Hydrogeology of Abuja FCT-Nigeria: A GIS Evaluation
}

\section{Richard Ayuk II Akoachere ${ }^{1 *}$, Omogbemi Omoloju Yaya², Areakpoh Thomson Eyong1, Elizabeth Orock Ayuk ${ }^{3}$, Ebot Sonia Egbe ${ }^{1}$}

\author{
${ }^{1}$ Department of Geology, University of Buea-Cameroon, Buea, Cameroon \\ ${ }^{2}$ National Water Resources Institute, Kaduna, Nigeria \\ ${ }^{3}$ Department of Environmental Sciences, University of Buea-Cameroon, Buea, Cameroon \\ Email: *r.akoachere@ubuea.cm
}

How to cite this paper: Akoachere, R.A., Yaya, O.O., Eyong, A.T., Ayuk, E.O. and Egbe, E.S. (2019) Hydrogeology of Abuja FCT-Nigeria: A GIS Evaluation. Open Access Library Journal, 6: e5649. https://doi.org/10.4236/oalib.1105649

Received: July 29, 2019

Accepted: August 25, 2019

Published: August 28, 2019

Copyright (C) 2019 by author(s) and Open Access Library Inc.

This work is licensed under the Creative Commons Attribution International License (CC BY 4.0).

http://creativecommons.org/licenses/by/4.0/

\section{c) (i) Open Access}

\begin{abstract}
Groundwater has been recognized as playing a very important role in the development of Abuja FCT Nigeria's capital, as many private and government establishments depend solely on wells for their water needs. Exploitation of groundwater is delicate due to its potency to contamination and difficulty to remediate aquifers. This study is to evaluate the input of the rock formations to the groundwater solute chemistry and groundwater domestic quality using hydrogeochemical tools and physicochemical parameters: $\mathrm{pH}, \mathrm{EC}$, Temperature, TDS, Chloro-alkaline indices, Ionic ratios, Gibbs diagrams, Piper diagrams, Durov diagrams and water quality index. From physicochemical parameters: $\mathrm{pH}$ ranged from, 4.8 - 7.9; EC, 13.4 - $1634 \mu \mathrm{S} / \mathrm{cm}$; Temperature, $26^{\circ} \mathrm{C}-36.1^{\circ} \mathrm{C}$ and TDS, $17.42-1094.78 \mathrm{mg} / \mathrm{L}$. The major ions fell below WHO acceptable limits. The sequences of abundance of major ions were, $\mathrm{K}^{+}>\mathrm{Ca}^{2+}>\mathrm{Na}^{+}>\mathrm{Mg}^{2+}$ for cations and $\mathrm{Cl}^{-}>\mathrm{HCO}_{3}^{-}>\mathrm{NO}_{3}^{-}>\mathrm{SO}_{4}^{2-}$ for anions. Borehole depths range from 19.5 - $34.5 \mathrm{~m}$ with static water levels between 3 - 12 m.a.m.s.l. Yields were between $3.2-7.2 \mathrm{~m}^{3} / \mathrm{Hr}$. Ionic ratios show ninety-five (95\%) percent of the groundwater chemistry resulting from chemical weathering of rock-forming minerals through the dissolution of the host rock. The Chloro-alkaline indices: $\mathrm{CAI}_{1} 87.23 \%$ are positive indicating exchange of $\mathrm{Na}$ and $\mathrm{K}$ from water with $\mathrm{Mg}$ and $\mathrm{Ca}$ of the rocks and $12.77 \%$ are negative, indicating reverse softening of groundwater in rocks by infiltrating rainwater while $\mathrm{CAI}_{2} 85.11 \%$ are positive indicating exchange of $\mathrm{Na}$ and $\mathrm{K}$ from water with $\mathrm{Mg}$ and $\mathrm{Ca}$ of the rocks and $14.89 \%$ are negative, indicating reverse softening of groundwater in rocks by infiltrating rainwater. Thus chloro-alkaline indices indicate the dominance of alkaline earth elements over alkalis in majority of samples due to direct exchange of $\mathrm{Ca}^{2+}$ and $\mathrm{Mg}^{2+}$ from the aquifer matrix with $\mathrm{Na}^{+}$and $\mathrm{K}^{+}$from the groundwater. Gibbs
\end{abstract}


diagram revealed groundwater ionic content was as a result of ion exchange from rock-weathering. Piper diagrams give three water types: $75 \%$ are $\mathrm{CaH}-$ $\mathrm{CO}_{3}, 21.20 \%$ are of $\mathrm{MgHCO}_{3}$ and 3.19\% are of $\mathrm{Na}+\mathrm{KHCO}_{3}$ water types respectively. Piper diagrams also give three hydrogeochemical facies in Abuja FCT: $54.25 \%$ are of $\mathrm{Ca}-\mathrm{Mg}-\mathrm{Cl}-\mathrm{SO}_{4}, 42.56 \%$ are of $\mathrm{Ca}-\mathrm{Mg}-\mathrm{HCO}_{3}$ and $3.19 \%$ are of Na-K-Cl-SO ${ }_{4}$ hydrogeochemical facies respectively. Durov plot shows $20.21 \%$ are anion discriminate Ca dominant; mixed water and $63.83 \%$ had no dominant ion; simple dissolution. Water quality indices (WQI) values were between $-220-180$, Total hardness $(\mathrm{TH})$ values were between $0-519.12$. These WQI and TH values indicate that $69.2 \%$ and $47.37 \%$ of the groundwater respectively are suitable for domestic purpose. The groundwater in Abuja FCT is acidic to slightly alkaline in nature, soft to moderately hard and of low to high salinity. Major processes controlling the water quality are the weathering of the host rock through mineral dissolution, cation exchange and inverse cation exchange processes. Ion-exchange, simple dissolution and uncommon dissolution processes determined groundwater character.

\section{Subject Areas}

Hydrology

\section{Keywords}

Chloro-Alkaline Indices, Ionic Ratios, Hydrogeochemical Facies, Domestic Water Quality, Abuja FCT

\section{Introduction}

The Federal Capital Territory (FCT) Abuja, bounded between $8^{\circ} 45^{\prime} \mathrm{N}-9^{\circ} 40^{\prime} \mathrm{N}$ and $6^{\circ} 50^{\prime} \mathrm{E}-8^{\circ} 55^{\prime} \mathrm{E}$ and covering an area of about $8000 \mathrm{~km}^{2}$ was conceived in 1976 with adequate allocation of resources, to be a model city of urbanization in sub-Saharan Africa. Before the birth of the FCT, Abuja and environs had been plagued with varying intensities of water shortages and crisis at the local government scale. As the Capital City emerged, the rate of influx of population outstripped the capacity to provide utilities, exacerbating the water crisis to a higher scale, mainly due to the following:

1) Natural causes stemming from the hydrogeology and the hydrology (Basement hard rock steep sloped aquiferous formations and the moderate rainfall regime).

2) Inadequate exploration/exploitation and unsustainable management practices amplified by shortfalls associated with lack of equipment and technological knowhow for monitoring and characterizing the groundwater reserves.

Understanding groundwater flow in this aquifer system is critically important in determining the ability of the aquifer system to sustain the needs for public water supply schemes, the transportation and flow of contaminants.

A GIS evaluation of the hydrogeology of this area is deemed necessary to cha- 
racterize the aquiferous formations, increase the knowledge on the rock/water interaction and suggest some measures to increase the quantity and quality of groundwater in this very important area.

Abuja will find its place in the sun but the future development and prosperity of Abuja and environs may depend on the availability of water.

Geochemical processes that control the quality of groundwater are currently a topic of increasing concern because groundwater is of vital economic and social importance. Groundwater quality is dependent on nature of bedrock, topography, geology, soils, climate, atmospheric precipitation and quality of the recharged water. Further, groundwater quality could be affected by means of subsurface geochemical reactions such as weathering, dissolution, precipitation, ion exchange and various biological processes as discussed in [1] [2]. The concept of hydrogeochemical facies can be used to denote the diagnostic chemical character of water in hydrologic systems. The facies reflect the effect of complex hydrogeochemical chemical processes in the subsurface as discussed in [3] occurring between the minerals of formation and groundwater to investigate the spatial variability of groundwater chemistry in terms of hydrogeochemical evolution.

According to [4], the chemistry of groundwater is not only related to the lithology of the area and the residence time, but also reflects inputs from the atmosphere, from soil and weathering processes as well as from pollution sources such as mining, land clearance, saline intrusion, industrial and domestic wastes.

The study aims to identify the hydrogeochemical processes, groundwater characteristics and groundwater quality which are important for groundwater exploitation and management in Abuja FCT.

\subsection{Location}

The study area lies between $8.92 \mathrm{~N}-9.20 \mathrm{~N}$ and 7.25E - 7.60E in Abuja Federal Capital Territory (FCT) as seen in Figure 1. It is bounded in the east by Nasarawa State, north by Kaduna State, west by Niger State and south by Kogi State.

\subsection{Physiology}

The topography of Abuja is undulating with hills and inselbergs that rise northwestwards to a maximum of $1060 \mathrm{~m}$ above sea level. There are extensive plains found between hills in the study area. The Zuma rock stands out clearly on its own as the most conspicuous Inselberg at the boundary of the Abuja with Niger State. The lowest elevations are in the southwestern flood plains of the River Gurara, about $76 \mathrm{~m}$ above sea level. The rivers rise from the hills in the northeast and flow to the southwest. The area is drained by many rivers in and around Abuja including Rivers Gwagwalada and Usmanu while Rivers Wupa, Wosika and other smaller seasonal southerly-flowing streams form the tributaries and drain the study area. The drainage pattern generally varies from trellis to dendritic.

The major rivers join at Nyimbo village to form a tributary of River Niger in 


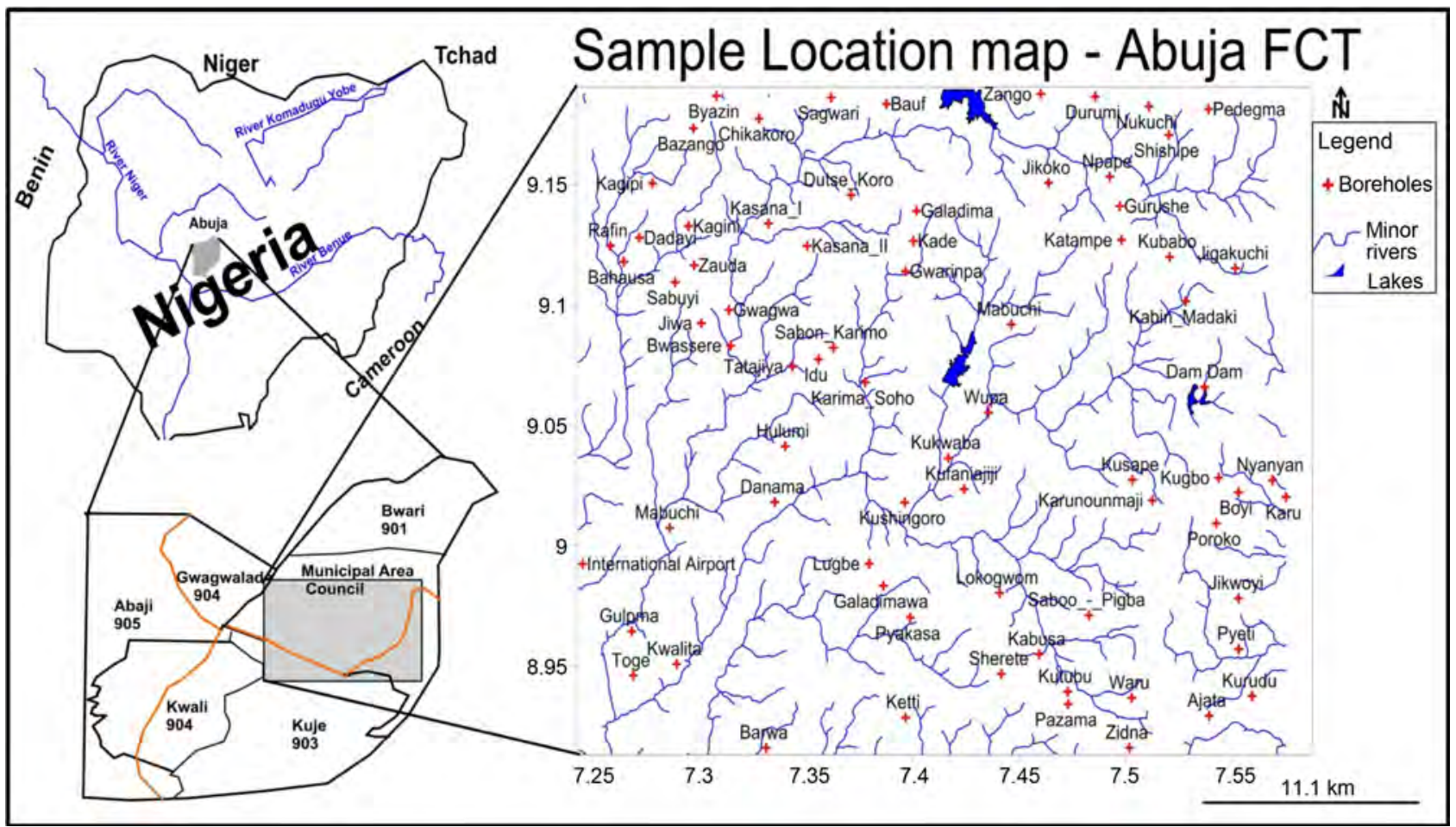

Figure 1. Location of the study area showing field tested and sampling points.

the south. These rivers depend on rainfall for their recharge. As such, their stages are high in rainy season and decrease drastically during the dry season.

\subsection{Climate}

The area has its highest temperature of about $36^{\circ} \mathrm{C}$ during the dry season, November to March. During the rainy season April to October, the temperature drops to a maximum of $24^{\circ} \mathrm{C}$. The annual rainfall ranges from $1100 \mathrm{~mm}$ to 1600 $\mathrm{mm}$ as discussed in [5]. Two types of vegetation occur; the forest predominantly of woody plants thorn bushes and trees in which grasses are virtually absent comprise mainly of secondary forest, which is continuously degraded for subsistence farming and habitation and the savanna herbs and shrubs, the study area being in Guinean Savanna Vegetation Zone of Nigeria.

\subsection{Hydrogeology}

There are seven subsurface aquiferous layers in the study area: 1) Topsoil, 2) Lateritic sand, 3) Clayey sand, 4) Weathered basement rock, 5) weathered/fractured basement rock, 6) Fresh/non-fractured basement rock and vii. Fresh fractured basement. There are numerous long and short fractures at depths ranging from $7.0 \mathrm{~m}$ to $36.00 \mathrm{~m}$ running through these layers whose structural trends are mainly in northeast-southwest direction corresponding to the major tectonic structural trend of the basement complex in Nigeria as discussed in [6] [7]. The topsoil is aquiferous down the valleys (Hand-dug wells) and progressively unsaturated as we go uphill. 


\subsection{Geology}

The geology of the study area has been described by many workers, including [8] [9] [10]. The study area is underlain by Precambrian rocks of the Nigerian Basement Complex which cover about $85 \%$ of the land surface and cretaceous sedimentary rocks belonging to the Bida Basin which cover the remaining $15 \%$.

From field mapping, the major lithological units found in the study area are: Migmatite-gneiss; Biotite granites; Quartzites/Quartzite-schists; Amphibolite-Schists/Amphibolites as seen in Figure 2.

These Basement complex rocks are subdivided into:

1) The older metasediments

The migmatite gneiss complex is the commonest rock type in the Nigerian Basement complex. It comprises two main types of gneisses: the biotite gneiss and the banded gneiss. Very widespread, the biotitic gneisses are normally fine-grained with strong foliation caused by the parallel arrangement of alternating dark and light minerals. These banded gneisses show alternating light-colored and dark bands and exhibit intricate folding of their bands. The migmatite gneiss complex is the oldest basement rock, and is believed to be of

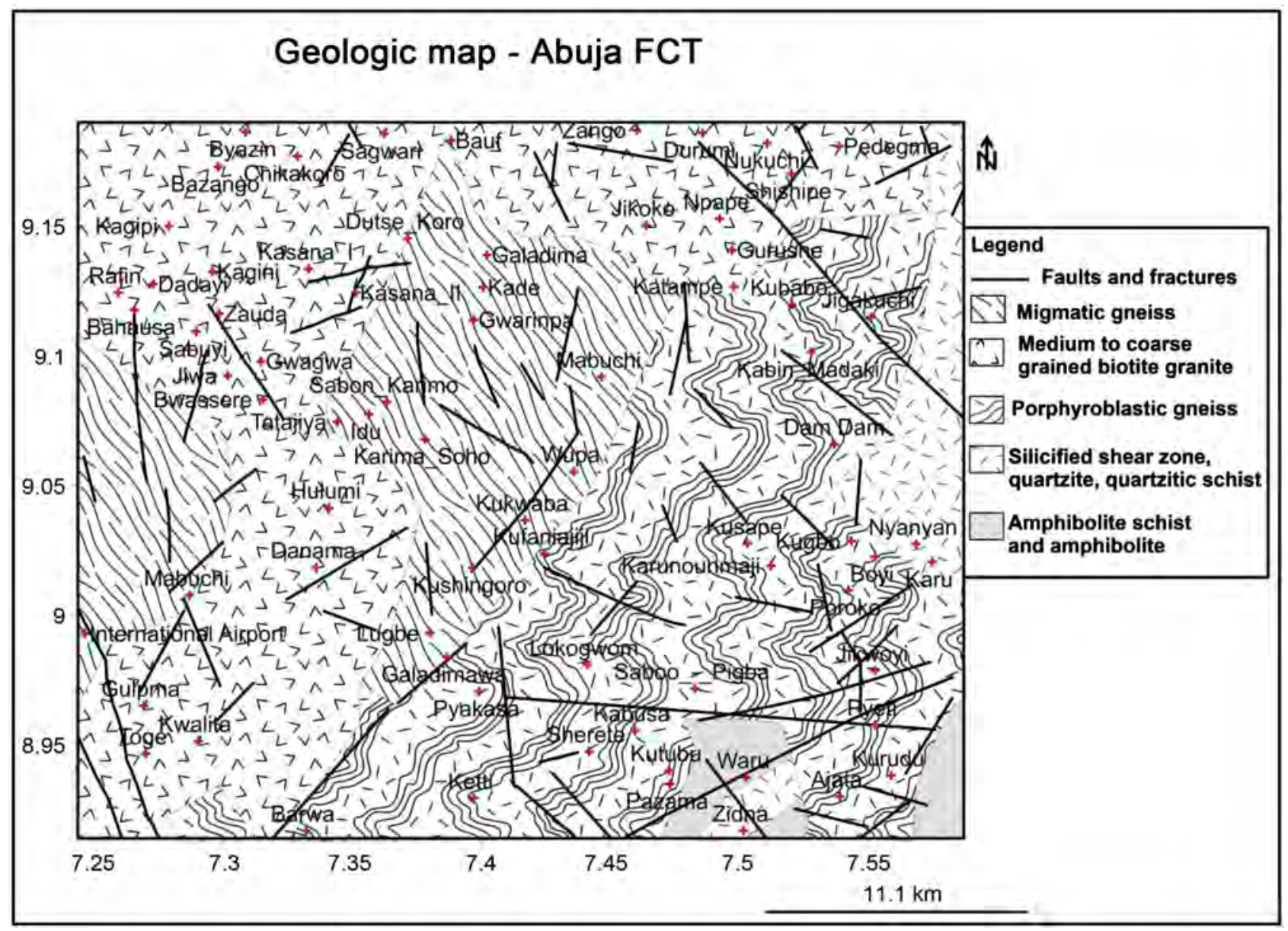

Figure 2. Geology of Abuja FCT. Comprising mainly of migmatite gneiss, biotite gneiss, porphyroblastic gneiss, quartzitic schists, amphibolitic schists and amphibolites. 
sedimentary origin but was later profoundly altered into metamorphic and granite conditions. The older metasediments were also among the earliest rocks to form on the Nigerian Basement Complex. Initially of sedimentary origin, with a more extensive distribution, the older metasediments underwent prolonged, repeated metamorphism; and now occur as quartzites (ancient sandstones), marble (ancient limestones), and other calcareous and relics of highly altered clayey sediments and igneous rocks.

2) The younger metasediments

Most parts of the Basement complex are underlain by belts of roughly north-south trending, slightly metamorphosed ancient Pre-cambrian sedimentary and volcanic rocks known as the younger metasediments with major rock types being ancient shaly rocks which are now referred to as quartz- biotite-muscovite schist. These change laterally into coarse-grained feldspar-bearing micaceous schists and schists in which graphite, phyllites and chlorite are common. Ferruginous quartzites also occur.

3) The older granites

The older granites vary extensively in composition. There is enormous variety in the granite composition of these rocks.

4) The younger granites

Granitic alkaline ring complexes and the intruding volcanic rock.

\section{Materials and Methods}

\subsection{Field Mapping, Measurements and Sampling}

Ninety-four (94) groundwater samples were collected from productive boreholes in the study area after a geological traverse field mapping exercise and borehole water field testing for physico-chemical parameters, following standard sampling protocols as discussed in [11]. Table 1 demonstrates geographical locations of tests sites in the study area.

Boreholes for tests and measurements were selected based on three criteria:

1) Availability of data, 2) Being functional and in use, 3) Not deeper than our water level indicator $50 \mathrm{~m}$ and Sonar bottom sounder $61 \mathrm{~m}$. Groundwater samples were analyzed as discussed in [12] at Activation Laboratory (Actlabs), Canada. The following groundwater and borehole physical parameters were measured in-situ in the field using calibrated field instruments; Hanna HI 98127 (pH), HI 98304 (EC), HI 96304 (TDS), HI 9147 (DO), Groundwater temperature and electrical conductivity in boreholes was profiled real-time using Solinst levelogger for Static Water Level measurements. Geolocation and elevation measurements of boreholes were done using a Global Positioning System (GPS) Garmin 60CSx.

Water level measurements are useful in hydrogeology to:

1) Determine the ease of groundwater exploration, exploitation and distribution.

2) Determine groundwater flow direction, gradient and yields. 
Table 1. Location of water samples for chemical analysis and physico-chemical measurements.

\begin{tabular}{|c|c|c|c|c|c|c|c|c|c|c|c|}
\hline SN & Name & $\mathrm{N}$ & $\mathrm{E}$ & $\mathrm{SN}$ & Name & $\mathrm{N}$ & $\mathrm{E}$ & $\mathrm{SN}$ & Name & $\mathrm{N}$ & $\mathrm{E}$ \\
\hline 1 & Kwalita & 7.2499 & 8.9540 & 33 & Toge & 7.3356 & 8.9487 & 64 & Galadima & 7.3796 & 9.1674 \\
\hline 2 & Kwalita & 7.2496 & 8.9532 & 34 & Sherete & 7.3337 & 8.9489 & 65 & Gwagwa & 7.3354 & 9.1017 \\
\hline 3 & Pazama & 7.2547 & 8.9332 & 35 & Pyakasa & 7.3567 & 8.9686 & 66 & Gwagwa & 7.4081 & 9.1011 \\
\hline 4 & Zidna & 7.2152 & 8.9134 & 36 & Saboo_Pigba & 7.3723 & 8.9673 & 67 & Gwagwa & 7.4081 & 9.1011 \\
\hline 5 & Kabusa & 7.2941 & 8.9453 & 37 & Lokogwom & 7.3730 & 8.9700 & 68 & Gwagwa & 7.4097 & 9.1018 \\
\hline 6 & Kutubu & 7.2916 & 8.9448 & 38 & Galadimawa & 7.3738 & 8.9804 & 69 & Gwarinpa & 7.4177 & 9.1060 \\
\hline 7 & Gulpma & 7.2432 & 8.9549 & 39 & Kasana_I & 7.3677 & 8.9983 & 70 & Gurushe & 7.4670 & 9.1408 \\
\hline 8 & Jigakuchi & 7.2893 & 8.9967 & 40 & Jikoko & 7.3711 & 8.9963 & 71 & Zango & 7.5200 & 9.1610 \\
\hline 9 & Jikoko & 7.3193 & 9.0040 & 41 & Jikwoyi & 7.4203 & 9.0184 & 72 & Zango & 7.4915 & 9.1012 \\
\hline 10 & Kusape & 7.3305 & 9.0278 & 42 & Dutse_Koro & 7.4227 & 9.0179 & 73 & Jiwa & 7.4367 & 9.0947 \\
\hline 11 & Kushingoro & 7.3504 & 9.0298 & 43 & Dutse_Koro & 7.4427 & 9.0175 & 74 & Byazin & 7.4339 & 9.0952 \\
\hline 12 & Hulumi & 7.3714 & 9.0449 & 44 & Kabin_Madaki & 7.4224 & 9.1032 & 75 & Karu & 7.5690 & 9.0291 \\
\hline 13 & Dam Dam & 7.3633 & 9.0714 & 45 & Zauda & 7.3990 & 9.1249 & 76 & Kugbo & 7.5685 & 9.0292 \\
\hline 14 & Kubabo & 7.3345 & 9.0766 & 46 & Dadayi & 7.3877 & 9.1288 & 77 & Kugbo & 7.5650 & 9.0281 \\
\hline 15 & Bahausa & 7.2810 & 9.1093 & 47 & Chikakoro & 7.3668 & 9.1376 & 78 & Kugbo & 7.5770 & 9.0294 \\
\hline 16 & Kasana_II & 7.2877 & 9.1166 & 48 & Npape & 7.3671 & 9.1375 & 79 & Kugbo & 7.5751 & 9.0328 \\
\hline 17 & Kurudu & 7.2979 & 9.0993 & 49 & Npape & 7.2989 & 9.1350 & 80 & Kugbo & 7.5624 & 9.0123 \\
\hline 18 & Sabon_Karimo & 7.3083 & 9.0804 & 50 & Npape & 7.3002 & 9.1350 & 81 & Kugbo & 7.3423 & 9.0064 \\
\hline 19 & Mabuchi & 7.3067 & 9.0913 & 51 & Npape & 7.3002 & 9.1350 & 82 & Katampe & 7.5205 & 9.0383 \\
\hline 20 & Mabuchi & 7.3133 & 9.0901 & 52 & Kasana_I & 7.3002 & 9.1350 & 83 & Katampe & 7.5205 & 9.0383 \\
\hline 21 & Ketti & 7.2821 & 9.0710 & 53 & Kagini & 7.2989 & 9.1320 & 84 & Katampe & 7.5194 & 9.0177 \\
\hline 22 & Poroko & 7.3318 & 9.0080 & 54 & Kade & 7.3008 & 9.1280 & 85 & Boyi & 7.5176 & 9.0169 \\
\hline 23 & Karima_Soho & 7.3544 & 9.0711 & 55 & Chikakoro & 7.3161 & 9.1430 & 86 & Ajata & 7.4882 & 9.0029 \\
\hline 24 & Idu & 7.4479 & 9.0817 & 56 & Kagipi & 7.3209 & 9.1532 & 87 & Barwa & 7.4683 & 9.0846 \\
\hline 25 & Wupa & 7.4102 & 9.0633 & 57 & Bazango & 7.3200 & 9.1520 & 88 & Sabuyi & 7.4809 & 9.0991 \\
\hline 26 & Danama & 7.4108 & 9.0239 & 58 & Shishipe & 7.3257 & 9.1704 & 89 & Durumi & 7.4809 & 9.0991 \\
\hline 27 & Pazama & 7.3972 & 8.9920 & 59 & Pedegma & 7.3277 & 9.1766 & 90 & Rafin & 7.4870 & 9.1026 \\
\hline 28 & Pazama & 7.3944 & 8.9994 & 60 & Bauf & 7.3261 & 9.1773 & 91 & Rafin & 7.4826 & 9.1009 \\
\hline 29 & Intl. Airport & 7.4025 & 8.9904 & 61 & Sagwari & 7.3326 & 9.1802 & 92 & Rafin & 7.4887 & 9.1020 \\
\hline 30 & Kufaniajiji & 7.4269 & 8.9917 & 62 & Nukuchi & 7.3382 & 9.1735 & 93 & Rafin & 7.4744 & 9.0757 \\
\hline 31 & Kukwaba & 7.3049 & 8.9377 & 63 & Galadima & 7.3735 & 9.1392 & 94 & Rafin & 7.4792 & 9.0658 \\
\hline 32 & Waru & 7.3265 & 8.9415 & & & & & & & & \\
\hline
\end{tabular}

3) Determine aquifer parameters $\mathrm{K}, \mathrm{T}, \mathrm{S}$ and estimate recharge rates.

4) Determine short and long-term periodic changes in amount of water in storage.

5) Understand the mechanics of the aquifer's matrix-fluid interaction. 
6) Gain insight for well construction, development and efficient extraction.

Estimation of the Sustainable yield of a borehole.

The ratio of drawdown s to pumping rate $Q$ is a constant for a well (if corrected for well losses). This constant only depends on the aquifer property transmissivity $T$ and shall not exceed a maximum drawdown $s_{\text {Available }}$, the extrapolation of the measured pumping test drawdown can be used to determine the sustainable yield:

$$
Q_{\text {Sustainable }}=Q_{\text {Pump Test }} \frac{S_{\text {Available }}\left(t=t_{\text {long }}\right)}{S_{\text {Pump Test }}\left(t=t_{\text {long }}\right)} \quad \text { [13] }
$$

The available drawdown is for instance the position of the main water strike in the borehole. If the drawdown exceeds this position and a drastic decrease in the yield of the borehole occurs, it may dry up. The problem of extrapolating the drawdown measured during the pumping test from the time of the end of the pumping test $(t)$ to a time ( $t_{\text {long }}$ ) of around two to five years remains a compulsory requirement. This extrapolation is traditionally done by applying the Theis solution. A more sophisticated extrapolation of the pumping test drawdown beyond the time of the end of the measurement is obtained by using a Taylor series expansion based on the extrapolation of the measured drawdown curve including drawdown derivatives, and by accounting for boundaries as discussed in [13].

\subsection{Chloro Alkaline Indices (CAI)}

As discussed by [14] [15] [16] there are two Chloro-Alkaline Indices $\mathrm{CAI}_{1}$ and $\mathrm{CAI}_{2}$ for the interpretation of ion exchange between the groundwater and its surroundings during residence and/or travelling time in the aquifer.

The Chloro-Alkaline Indices are calculated from the following formula demonstrated in Table 2.

A positive value of $\mathrm{CAI}_{1}$ indicates there has been an exchange of sodium and potassium $\left(\mathrm{Na}^{+}+\mathrm{K}^{+}\right)$in the groundwater with calcium and magnesium $\left(\mathrm{Ca}^{2+}+\right.$ $\mathrm{Mg}^{2+}$ ) ions in weathered materials in the rocks by a type of base-exchange reaction. During this process, the host rocks are the primary sources of dissolved solids in the water. A negative value of $\mathrm{CAI}_{1}$ represents the absence of base-exchange reactions.

Table 2. Indices used in the calculation of water quality.

\begin{tabular}{ccc}
\hline & Formula & Reference \\
\hline Total Hardness & $\mathrm{TH}\left(\mathrm{CaCO}_{3}\right) \mathrm{mg} / \mathrm{L}=2.5 \mathrm{Ca}^{2+}+4.1 \mathrm{Mg}^{2+}$ & {$[1]$} \\
Water Quality Index & $W Q I=\sum_{i=1}^{n} W_{i} q_{i}\left[\sum_{i=1}^{n} W_{i}\right]^{-1}$ & {$[20]$} \\
$\mathrm{CAI}_{1}$ & $[\mathrm{Cl}-(\mathrm{Na}+\mathrm{K})] / \mathrm{Cl}]$ & {$[14][15][16]$} \\
$\mathrm{CAI}_{2}$ & $\left.[\mathrm{Cl}-(\mathrm{Na}+\mathrm{K})] / \mathrm{SO}_{4}+\mathrm{HCO}_{3}+\mathrm{CO}_{3}+\mathrm{NO}_{3}\right]$ & {$[14][15][16]$} \\
\hline
\end{tabular}


Ionic ratio for indicative elements is a useful hydrogeochemical tool to identify source rock of ions and formation contribution to solute hydrogeochemistry as discussed in [17]. These were used in this study.

Gibbs Diagram is a plot of $\mathrm{Na}^{+} /\left(\mathrm{Na}^{+}+\mathrm{K}^{+}+\mathrm{Ca}^{2+}\right)$ and $\mathrm{Cl}^{-} /\left(\mathrm{Cl}+\mathrm{HCO}_{3}^{-}\right)$as a function of TDS are widely employed to determine the sources of dissolved geochemical constituents. These plots reveal the relationships between water composition and the three main hydrogeochemical processes involved in ions acquisition; Atmospheric precipitation, rock weathering or evaporation crystallisation.

Pipers Diagram is a graphical representation of the chemistry of water sample on three fields; the cation ternary field with $\mathrm{Ca}, \mathrm{Mg}$ and $\mathrm{Na}+\mathrm{K}$ apices, the anion ternary field with $\mathrm{HCO}_{3}, \mathrm{SO}_{4}$ and $\mathrm{Cl}^{-}$apices. These two fields are projected onto a third diamond field. The diamond field is a matrix transformation of the graph of the anions [sulphate + chloride] $/ \Sigma$ anions and cations $[\mathrm{Na}+\mathrm{K}] / \Sigma$ cations. This plot is a useful hydrogeochemical tool to compare water samples, determine water type and hydrogeochemical facies as discussed in [18]. This has been used here for these purposes.

Durov diagram is a composite plot consisting of two ternary diagrams where the milliequivalent percentages of cations are plotted perpendicularly against those of anions; the sides of the triangles form a central rectangular binary plot of total cation vs. total anion concentrations. These are divided into nine classes by [19] which give the hydrogeochemical processes determining the character of the water types in the aquiferous formation as discussed in [18].

WQI was calculated by adopting Weighted Arithmetical Index method considering thirteen water quality parameters $(\mathrm{pH}, \mathrm{EC}, \mathrm{TDS}$, total alkalinity, total hardness, $\mathrm{Ca}^{2+}, \mathrm{Mg}^{2+}, \mathrm{Na}^{+}, \mathrm{K}^{+}, \mathrm{Cl}^{-}, \mathrm{SO}_{4}^{2-}, \mathrm{NO}_{3}^{-}, \mathrm{NH}_{4}^{+}$) in order to assess the degree of groundwater contamination and suitability as demonstrated in Table 2.

Data from the geological traverse field mapping, field tests, field measurements and laboratory analysis were placed on MS Excel spreadsheets, and then mounted unto various GIS and software platforms, Rockworks14, Surfer V12, Grapher, AQqa and Enviroinsite where they were vigorously queried as demonstrated in Table 3.

\section{Results and Discussion}

\subsection{Physicochemical Parameters}

The physicochemical parameters of groundwater in Abuja: Temperature, $\mathrm{pH}$, EC and TDS for 94 boreholes were evaluated and the basic statistics as demonstrated in Table 4.

\subsection{Borehole Depths}

Borehole depths ranged from $19.5 \mathrm{~m}$ to $34.5 \mathrm{~m}$, as seen in Figure 3. Borehole depth measurement is one of the first health checks for a borehole. It tells us 
Table 3. Field equipment, specifications and functions.

\begin{tabular}{|c|c|c|}
\hline Equipment/Softwares & Specifications & Functions \\
\hline GPS & Garmin GPSMAP 60CSx & $\begin{array}{l}\text { To measure longitude, latitude and } \\
\text { elevation of wells }\end{array}$ \\
\hline EC Meter & Hanna HI 98304/HI98303 & $\begin{array}{l}\text { To measure Electrical Conductivity } \\
\text { of water. }\end{array}$ \\
\hline pH Meter & Hanna HI 98127/HI98107 & To measure $\mathrm{pH}$ of water. \\
\hline Water level indicator & Solinst Model $102 \mathrm{M}$ & $\begin{array}{l}\text { To indicate static water levels of } \\
\text { water in wells }\end{array}$ \\
\hline Measuring Tape & Weighted measuring tape & $\begin{array}{l}\text { Measurement of well diameter and } \\
\text { depth. }\end{array}$ \\
\hline Digital Thermometer & $\begin{array}{l}\text { Extech } 39240\left(-50^{\circ} \mathrm{C} \text { to }\right. \\
\left.200^{\circ} \mathrm{C}\right)\end{array}$ & To measure temperature of water \\
\hline $\begin{array}{l}\text { Total Dissolved Solid } \\
\text { meter }\end{array}$ & Hanna HI 96301 with ATC & $\begin{array}{l}\text { To measure Total dissolved } \\
\text { solids in water }\end{array}$ \\
\hline Water sampler & Gallenkampf $1000 \mathrm{ml}$ & To collect well water sample from well \\
\hline Sample bottles & Polystyrene $500 \mathrm{ml}$ & $\begin{array}{l}\text { To hold sample for onward } \\
\text { transmission to laboratory }\end{array}$ \\
\hline Global Mapper & Version 15 & GIS Geolocation of wells \\
\hline $\begin{array}{l}\text { Surfer Golden } \\
\text { Software }\end{array}$ & Version 12 & $\begin{array}{l}\text { GIS plotting contours for spatial } \\
\text { distribution }\end{array}$ \\
\hline AqQA/Aquachem & Version 1.5 & $\begin{array}{l}\text { For the analysis/interpretation of } \\
\text { water chemistry }\end{array}$ \\
\hline Enviroinsite & Equis gis & $\begin{array}{l}\text { For the analysis/interpretation of } \\
\text { water chemistry }\end{array}$ \\
\hline
\end{tabular}

Table 4. Basic statistics of the physicochemical found in groundwater, min, max, mean and standard deviation.

\begin{tabular}{ccccc}
\hline Parameter & Min & Max & Mean & Std \\
\hline $\mathrm{T}\left({ }^{\circ} \mathrm{C}\right)$ & 26.0 & 36.1 & 31.35 & 2.19 \\
$\mathrm{PH}$ & 4.8 & 7.9 & 6.04 & 0.67 \\
$\mathrm{EC}(\mathrm{mS} / \mathrm{cm})$ & 13.4 & 1634 & 265.21 & 281.26 \\
$\mathrm{TDS}(\mathrm{mg} / \mathrm{L})$ & 17.42 & 1094.78 & 178.88 & 187.74 \\
\hline
\end{tabular}

how well the borehole was constructed, developed, correctness of the borehole initial data and its state during exploitation. Silt and sand may have settled at the bottom of a well, well construction diagrams may be unavailable or inaccurate. The thickness of weathered basement is $15 \mathrm{~m}-35 \mathrm{~m}$ with an average of $26 \mathrm{~m}$.

\subsection{Water Level Measurements}

In the study area, water levels for sampled wells ranged from 3 to over $12 \mathrm{~m}$ a.m.s.l. as seen in Figure 4.

The importance of water level measurements in aquiferous formations is one of the most understated, under-emphasized and most taken-for-granted 


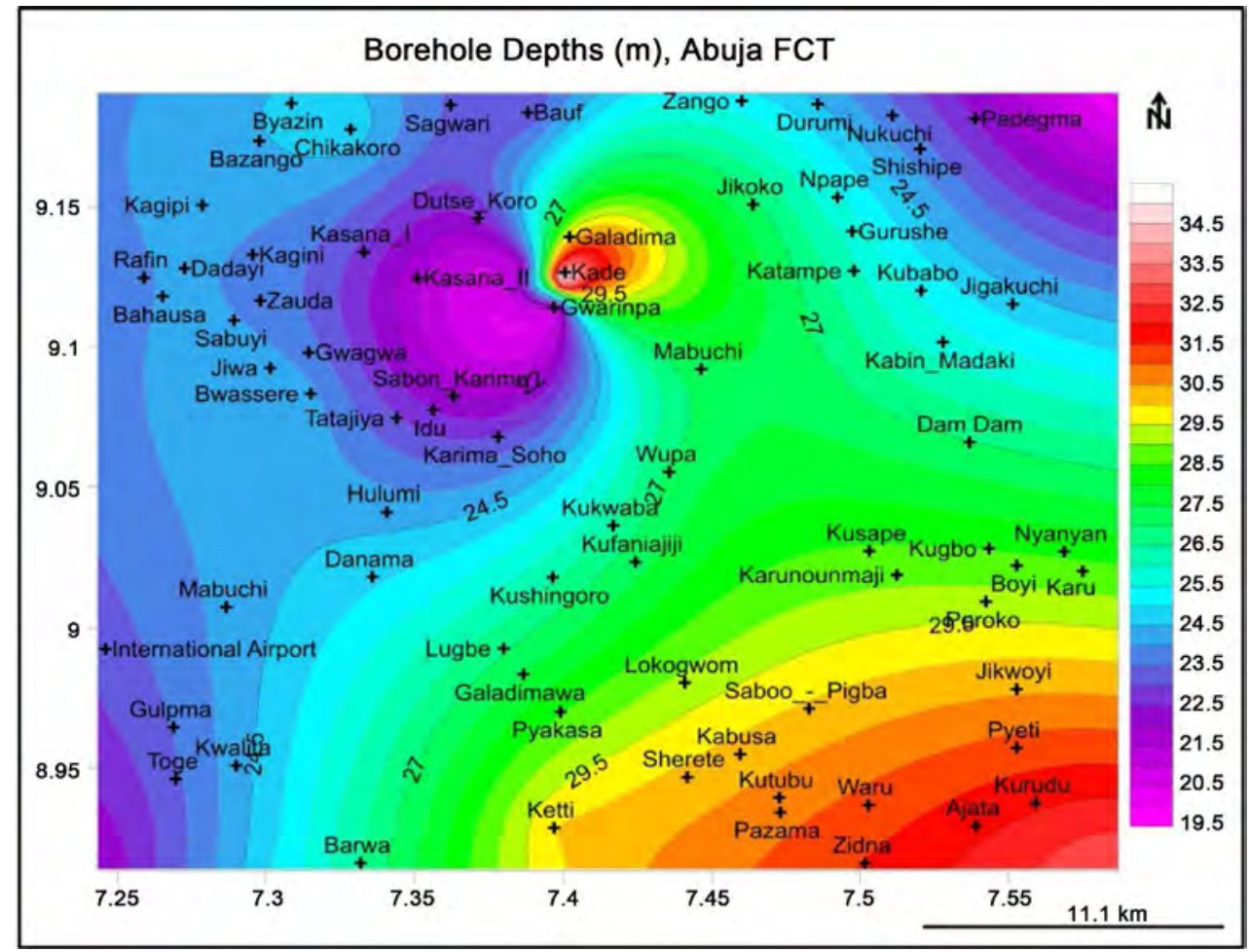

Figure 3. Spatial variation of borehole depths; deeper boreholes are at Kade, Galadima, Ajata, Pigba, Kurundu and Pyeti whereas low values are at Kasana, Pedegma, Toge and Karime.

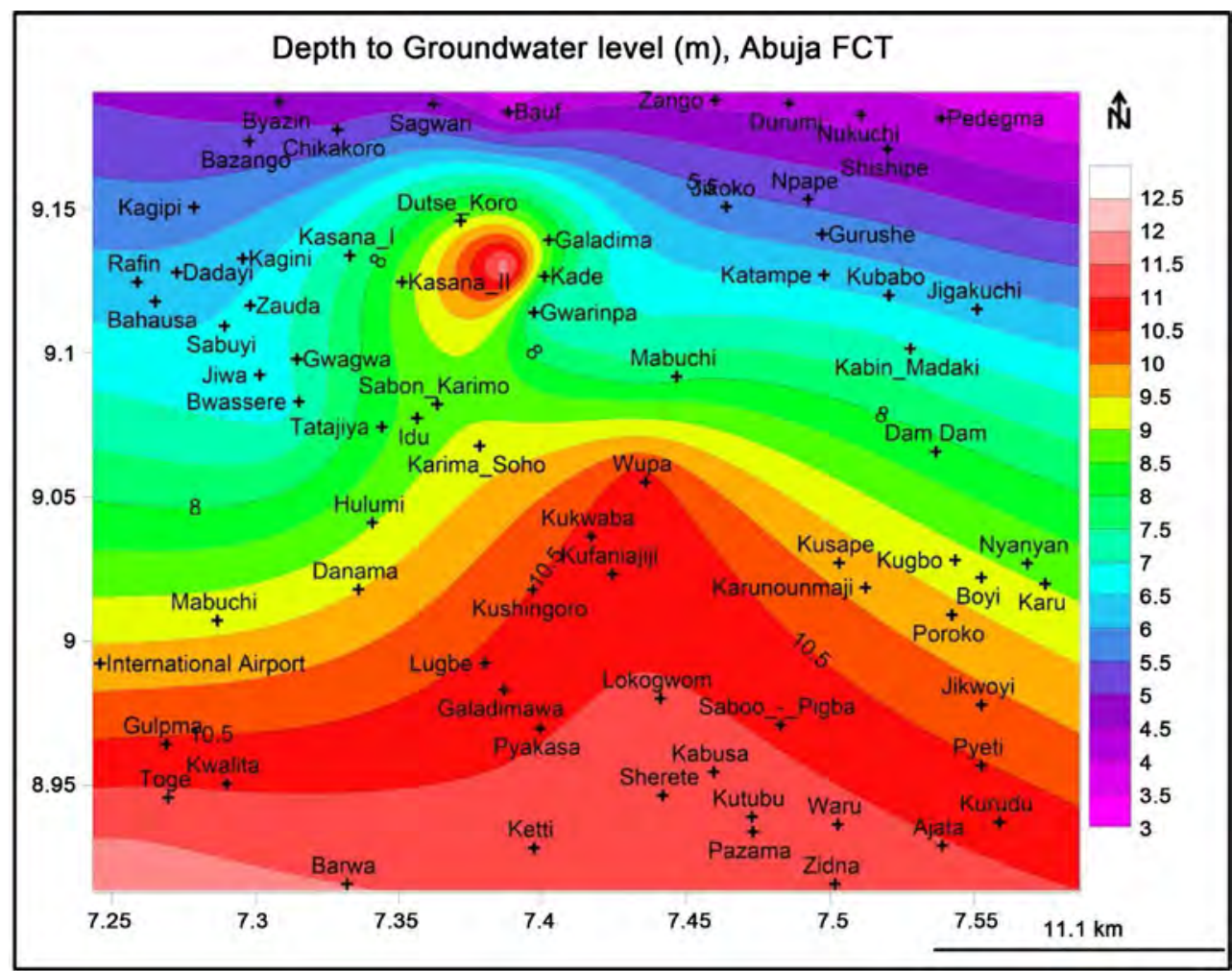

Figure 4. Depth to static water levels of Abuja groundwater. High values are at Kwalita, Galadimawa, Wupa, Pigba, Kurundu and Pyeti whereas low values are at Pedegma, Nukuchi, Durumi and Zango. 
parameters in hydrogeological investigations. How shallow or deep the groundwater level in an area is tells us a whole lot about the ease with which groundwater exploration, exploitation and distribution can be carried out in an area. Also, it tells us about the vulnerability of the aquifer to pollution and the surface/subsurface interaction of surface/groundwater. Measurements of water levels in wells provide the most fundamental indicator of the status of water resources and are critical to meaningful evaluations of the quantity and quality of ground water and its interaction with surface water. Water-level measurements from wells are the principal source of information about the hydrologic stresses acting on aquifers and how these stresses affect groundwater recharge, storage, and discharge. The water levels are relatively shallow and as such prone to pollution.

\subsection{Yield of Boreholes}

From driller's borehole tests data, the yield estimates were carried out within a maximum period of two days (48 hours) in the study area and ranged from 3.2 $\mathrm{m}^{3} / \mathrm{Hr}$. to $7.2 \mathrm{~m}^{3} / \mathrm{Hr}$ as seen in Figure 5 .

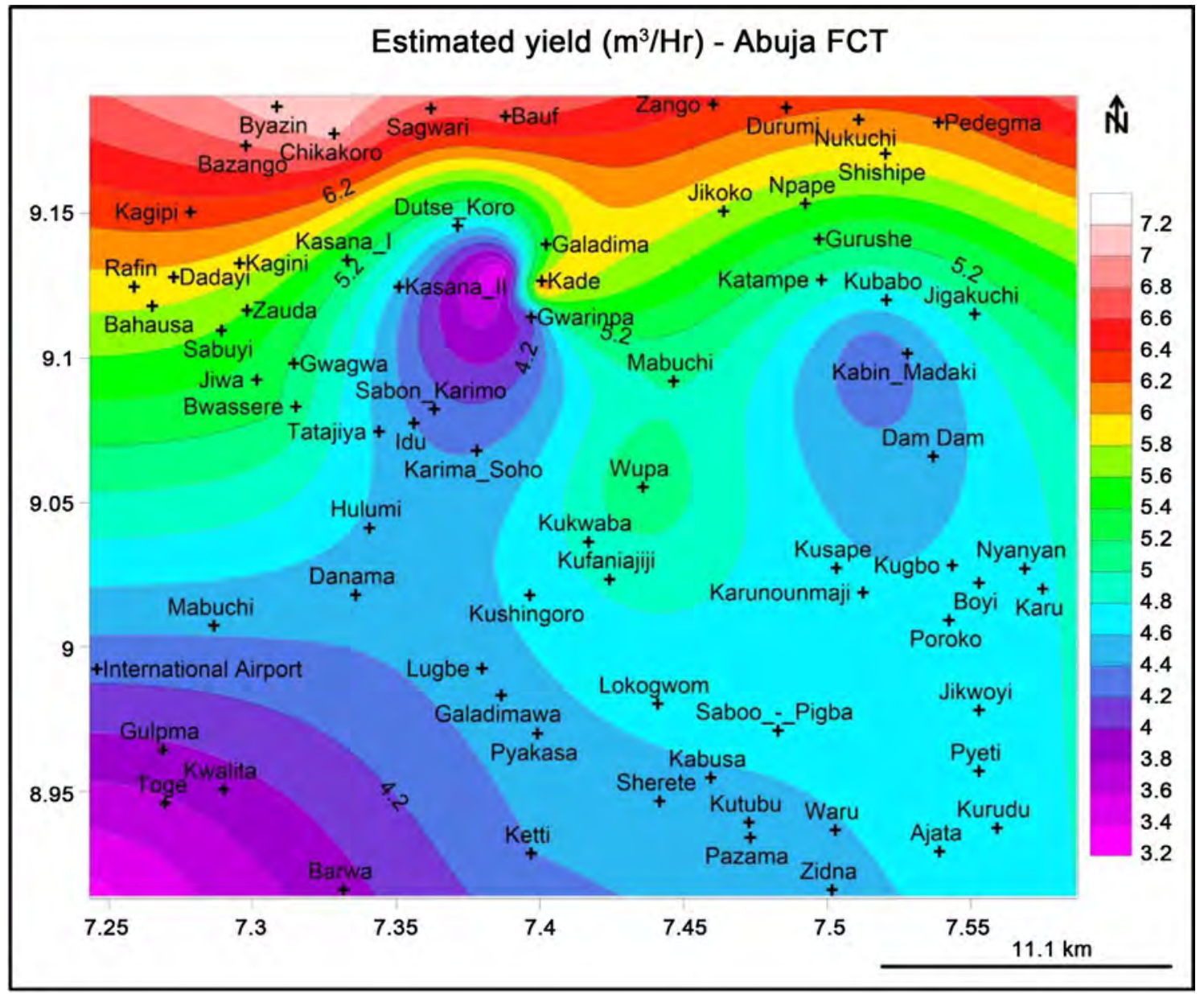

Figure 5. Spatial variation of estimated yield in Abuja; High values are at Byazin, Zango, Pedegma, Bazango and Chikakoro whereas low values are at Kasana, Toge, Barwa and Kwalita. 


\subsection{Temperature}

Profiled borehole groundwater temperatures were close to air temperatures, ranged from $26.5^{\circ} \mathrm{C}$ to $36^{\circ} \mathrm{C}$ and had no significant vertical variations, as seen in Figure 6. Profiling groundwater temperatures with depth in boreholes can be used to detect fracture positions, different aquiferous formations and systems through which the well has been drilled and also as a tracer to determine groundwater velocity as discussed in [21]. [22] used shallow subsurface temperatures to detect areas of increased flow to wells from riverbed infiltration, and to pinpoint zones of relatively better permeability in glacial outwash as discussed in [23] showed that variations in the smoother groundwater regional isotherm maps represented locations where differing land-use practices or groundwater movement disturbed the normal formational thermal system.

\section{6. $\mathrm{pH}$}

pondus Hydrogenium ( $\mathrm{pH}$ ): Weight of hydrogen ion in a solution; is a number

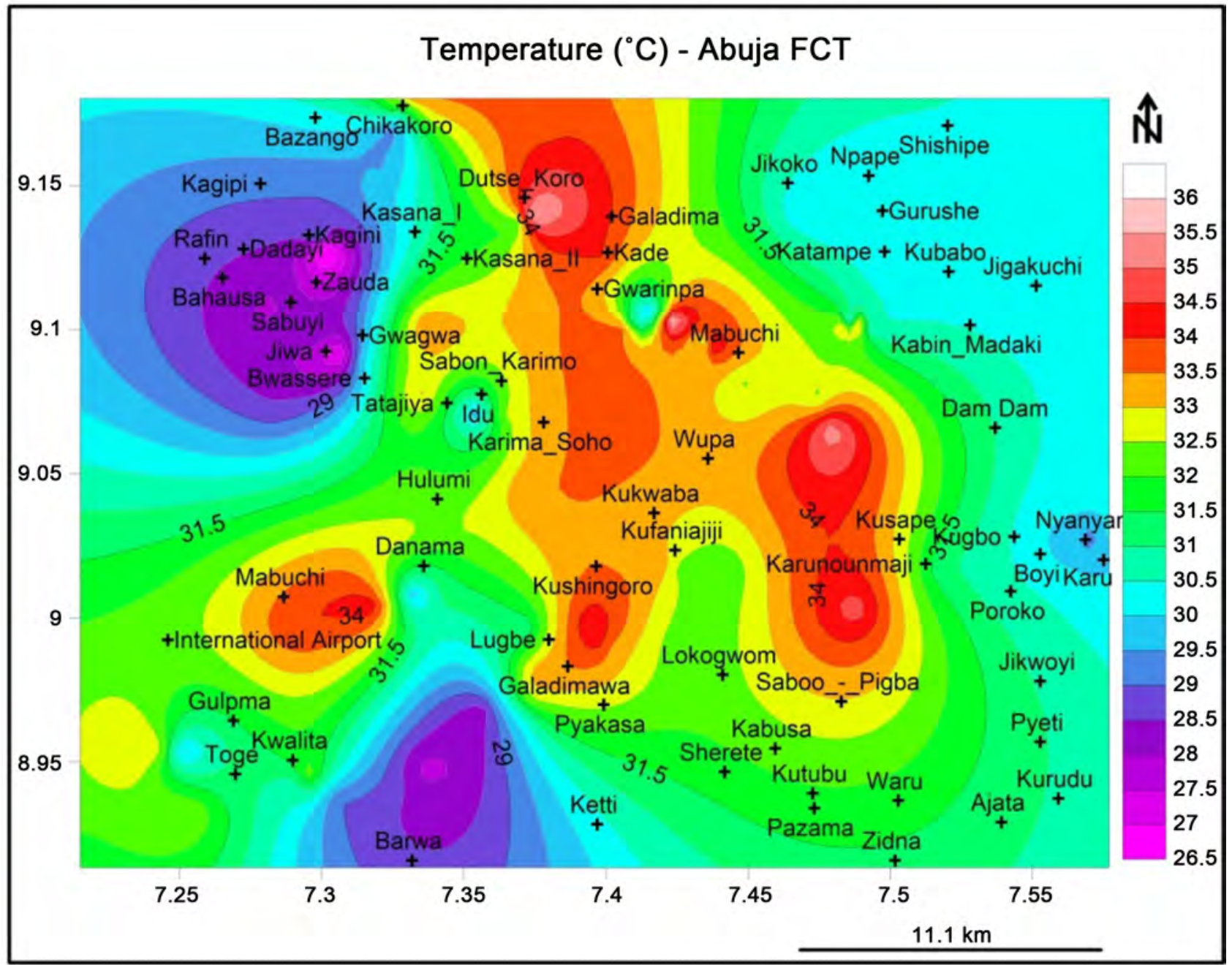

Figure 6. Spatial variation of temperature in Abuja; Note high temperature values around Koro, Kade, Galadima, Mabuchi, Kushingoro and Karunounmaji whereas low temperature values are at Kgjini, Jiwa, Dadayi, Sabuyi. 
(0 - 14) equal to the negative logarithm of the hydrogen ionic concentration. The value of $\mathrm{pH}$ of a water sample is recognized as an index of classifying groundwater as acidic < 5.5, slightly acidic $5.5-6.5$, neutral $6.5-7.5$, slightly alkaline 7.5 8 , moderately alkaline $8-9$ and alkaline $>9$.

The groundwater $\mathrm{pH}$ in the study area ranges from acidic $(<5.5)$; Saprock with leached horizon- $A$ as a result of precipitation and weathering, Neutral (6.5 - 7.5), humid climatic conditions having neutral environment with $\mathrm{Ca}$ and $\mathrm{Mg}$ as dominant ions; to slightly alkaline $(7.5$ - 8.0$)$ with measurable carbonate in the groundwater causing silica to be soluble and mobile as seen in Figure 7.

\subsection{Electrical Conductivity}

Electrical conductivity is used for indicating the total concentration of ions in a groundwater sample. It is closely related to the sum of cations (or anions) as determined chemically and usually correlates closely with the total dissolve solids. Since temperature affects chemical conductivity, it is customary to express it at $25^{\circ} \mathrm{C}$. The electrical conductivity ranges from 13.4 to 1634 with a mean of 265.21

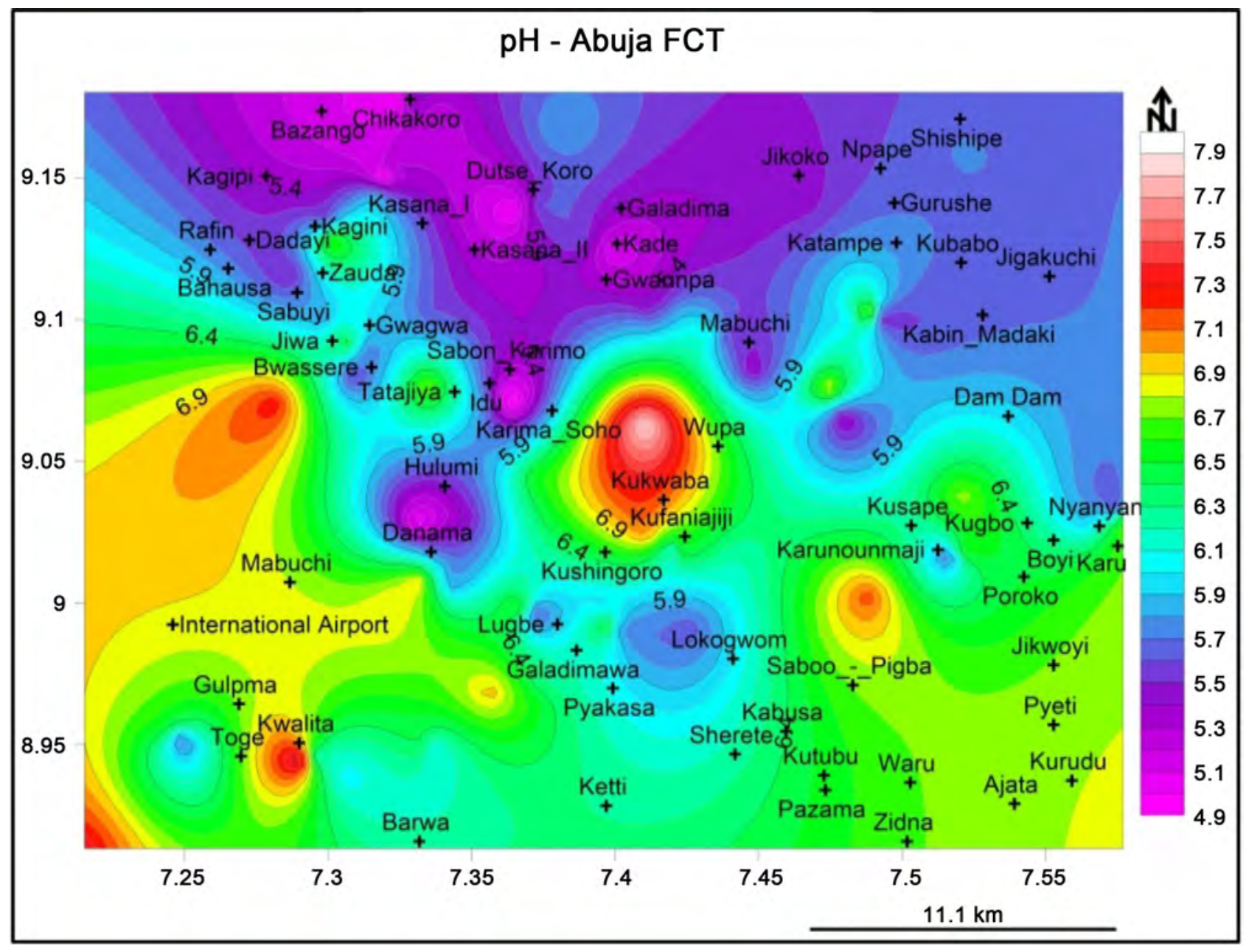

Figure 7. Spatial variation of $\mathrm{pH}$ in Abuja; Note high $\mathrm{pH}$ values around Kwalita, Kukwaba, Kufaniajiji whereas low $\mathrm{pH}$ values are at Danama, Bazango, Chikakoro, Dutse, Kade, and Galadima. 
as seen in Figure 8. (0 - 250) low salinity, (250 - 750) moderately saline water (750 - 2250) High saline waters, $>2250$ high concentration $\mathrm{Na}^{+}, \mathrm{HCO}_{3}$ and $\mathrm{CO}_{3}^{2-}$ ions characterized by high $\mathrm{pH}$.

\subsection{Total Dissolved Solids}

TDS values of groundwater in Abuja vary between $(<500 \mathrm{mg} / \mathrm{L})$ fresh water to (500 - $2000 \mathrm{mg} / \mathrm{L}$ ) slightly brackish water. This indicates the presence of some organics and silica in colloidal suspension. Total dissolved solid (TDS) is a measure of the combined content of all inorganic and organic substances contained in groundwater in molecular, ionized or micro-granular (colloidal sol) suspended form, used as an indicator test for the general quality of the water. Elevated total dissolved solids may suggest that toxic metals may be present at an elevated level. Very lower TDS concentration $(<100 \mathrm{mg} / \mathrm{L})$ may be corrosive and corrosive waters may leak toxic metals such as copper and lead from the household plumbing. This also means that trace metals could be present at levels that may pose a health risk as seen in Figure 9.

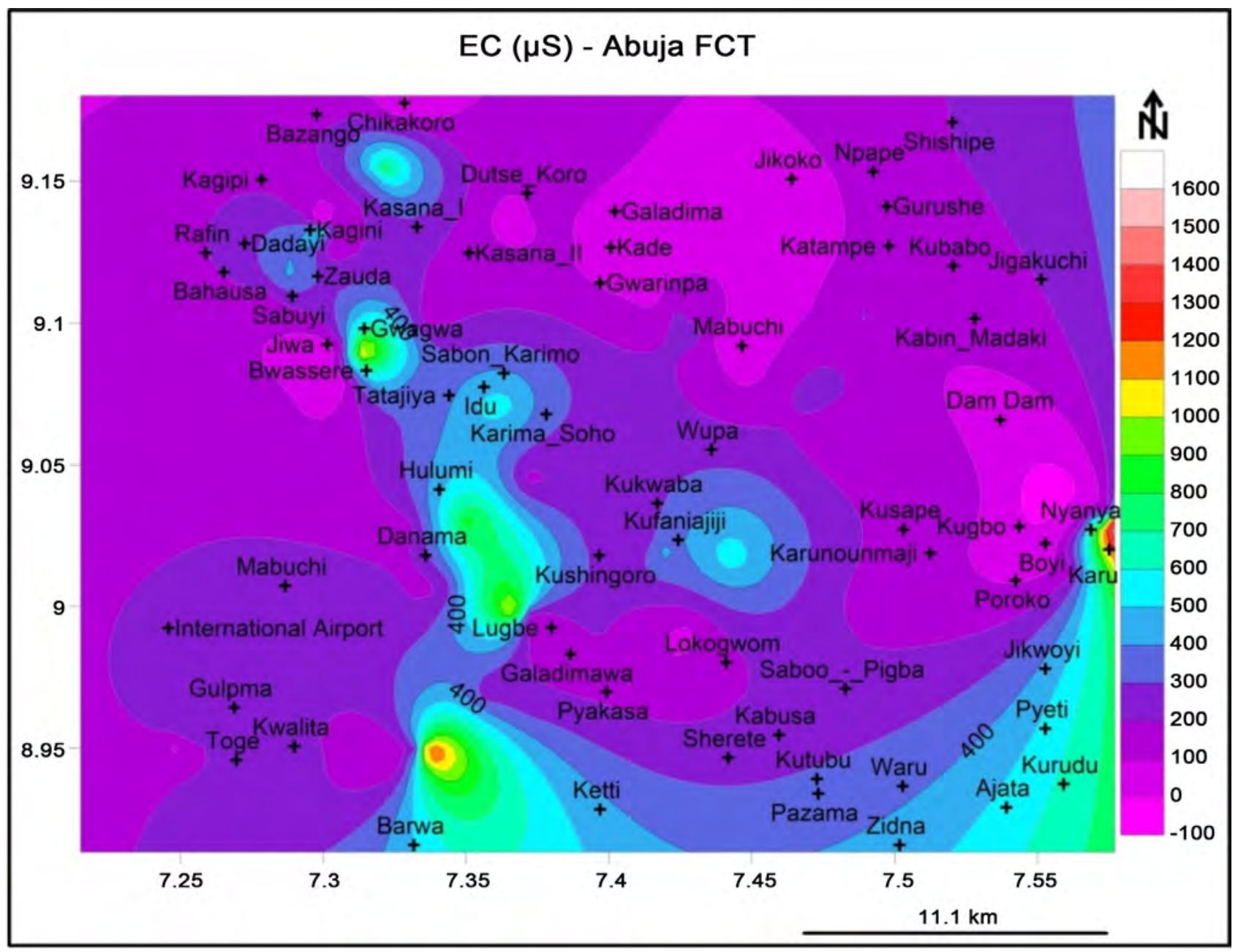

Figure 8. Spatial variation of Electrical Conductivity $(\mu \mathrm{S} / \mathrm{cm})$ in Abuja; EC is maximum at Kuru, Gwagwa, Kurundu, and Barwa whereas low values are at Nyana, Dam Dam, Jikoko, Galadima, Kade, Mabuchi, and Jikoko. 


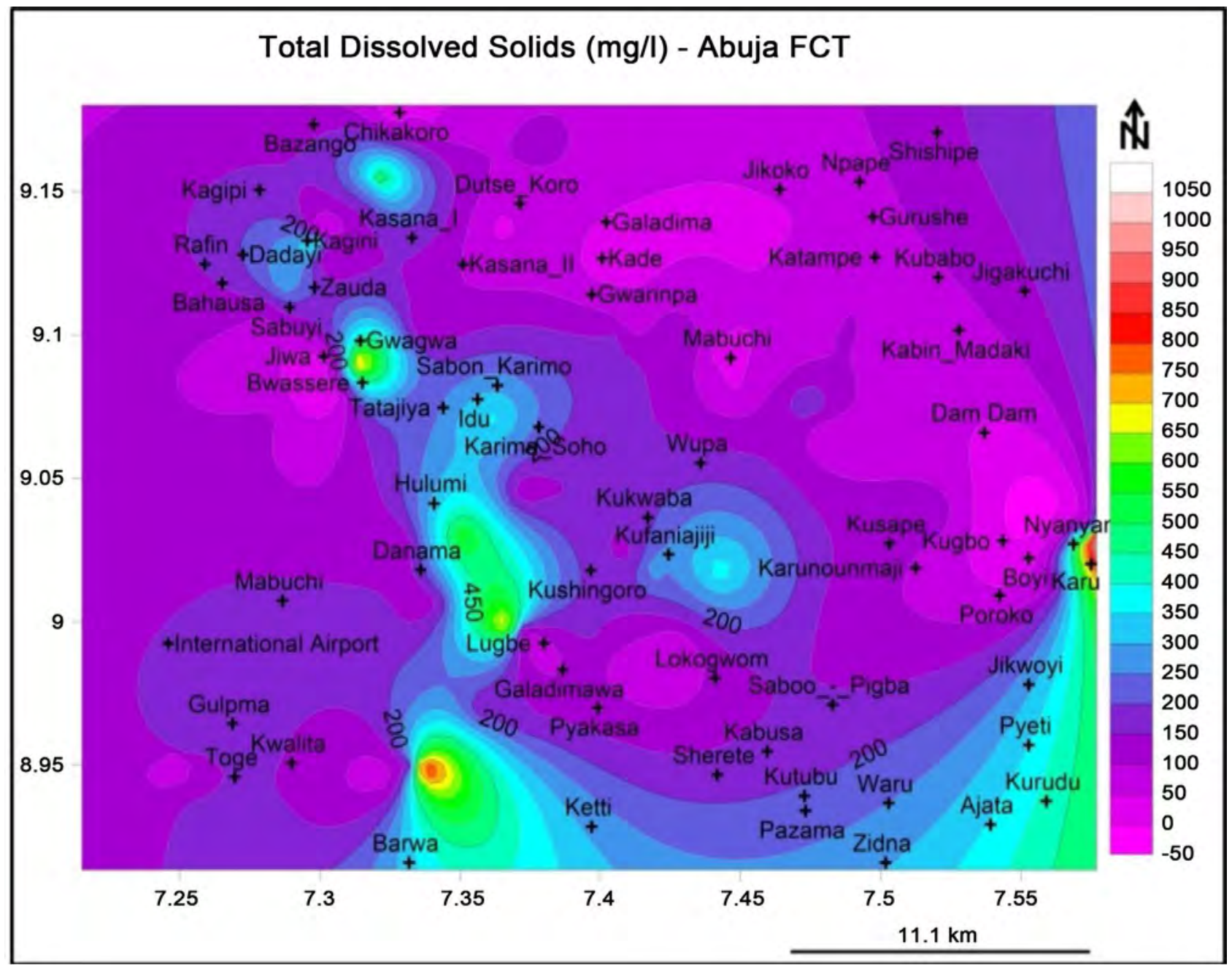

Figure 9. Spatial variation of Total dissolved solids (mg/L) in Abuja; TDS is maximum at Kuru, Gwagwa, Kurundu, and Barwa whereas low values are at Nyana, Dam Dam, Jikoko, Galadima, Kade, Mabuchi, and Jikoko.

\section{Groundwater Rock Interactions in Abuja}

\subsection{Parameter/Ionic Ratios}

Groundwater migrates through aquiferous formations over different space and time scales. During this process there are water/formation and water/formation-water interactions; dilution by percolating rainwater, inflow/outflow of fresher groundwater and (in shallow phreatic formations) effects of deep evapotranspiration and weathering. The result is groundwater mixing. Here absolute values of parameters and/or ionic concentrations can only give marginal groundwater interpretation indices. The use of parameter and ionic ratios is the most apt tool to enable a good interpretation of the hydrogeology of aquiferous formations.

\subsection{Indices of Base Exchange}

\subsubsection{Chloro Alkaline Indices (CAI-1)}

$\mathrm{CAI}_{1}$ values range from -3.25 to 9.62 as seen in Figure 10. All the computed 


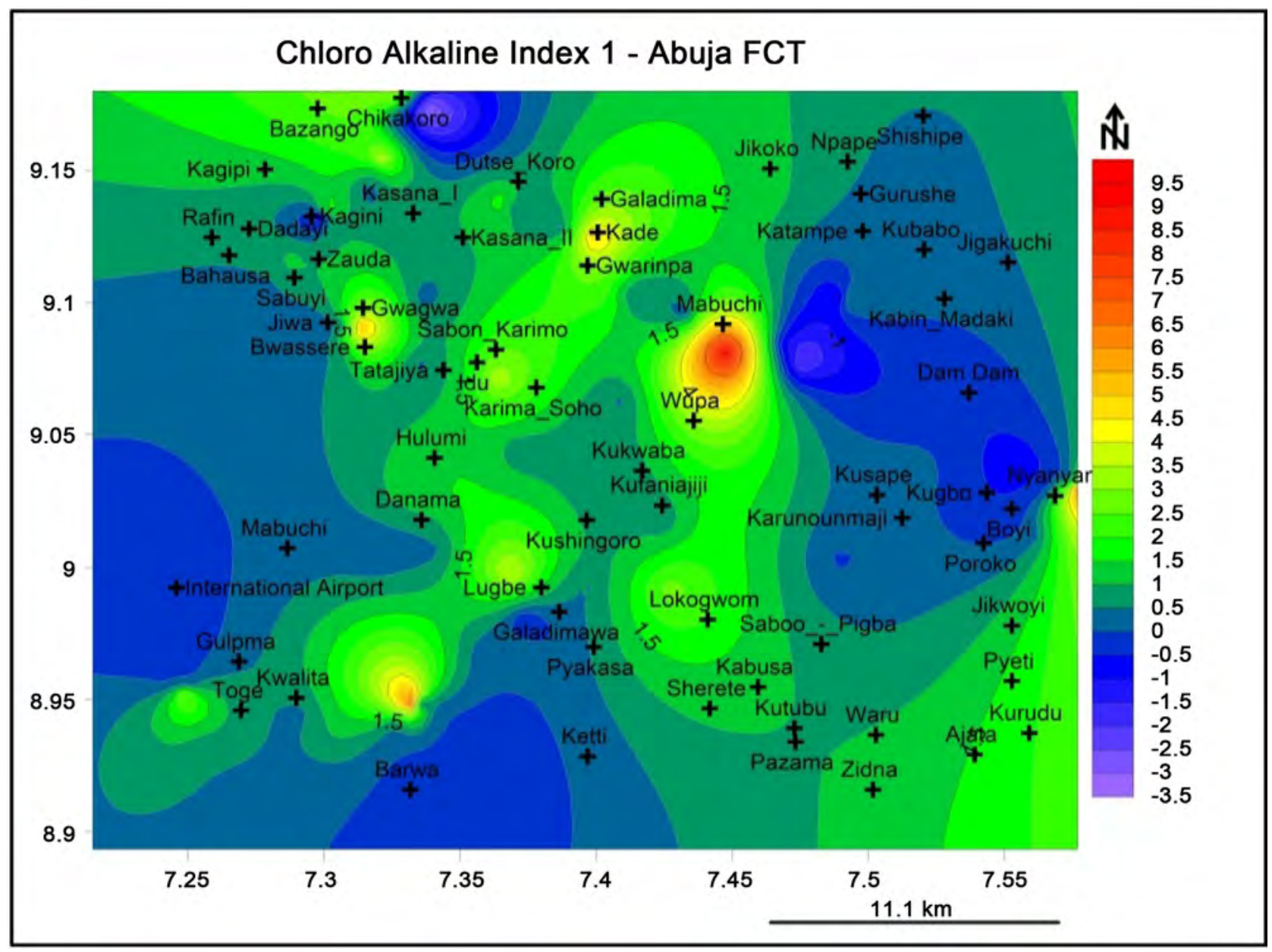

Figure 10. Spatial variation of Chloro alkaline index 1 in Abuja; $\mathrm{CAI}_{1}$ is maximum at Mabuchi, Kade and Gwagwa whereas low values are at Dam Dam, Barwa, Nyanyan, Boyi, Chikakoro and Kagini.

values of $\mathrm{CAI}_{1}$ (82 samples) $87.23 \%$ are positive indicating exchange of $\mathrm{Na}$ and $\mathrm{K}$ from water with $\mathrm{Mg}$ and $\mathrm{Ca}$ of the rocks and (12 samples) $12.77 \%$ are negative, indicating reverse softening of groundwater in rocks by infiltrating rainwater.

\subsubsection{Chloro Alkaline Indices (CAI-2)}

A positive value of $\mathrm{CAI}_{2}$ indicates chloro-alkaline disequilibrium and existence of cation-anion exchange type of reaction resulting in low salt waters where the major source of salts in the groundwater is rainfall or dissolution of gypsum in the aquiferous formation. $\mathrm{CAI}_{2}$ values range from -12.25 to 9.35 as seen in Figure 11. All the computed values of $\mathrm{CAI}_{2}$ (80 samples) $85.11 \%$ are positive indicating exchange of $\mathrm{Na}$ and $\mathrm{K}$ from water with $\mathrm{Mg}$ and $\mathrm{Ca}$ of the rocks and (14 samples) $14.89 \%$ are negative, indicating reverse softening of groundwater in rocks by infiltrating rainwater.

\subsection{Ionic Variation}

The relation between the different major ions has been elucidated through the determination of the ionic ratios as demonstrated in Table 5. 


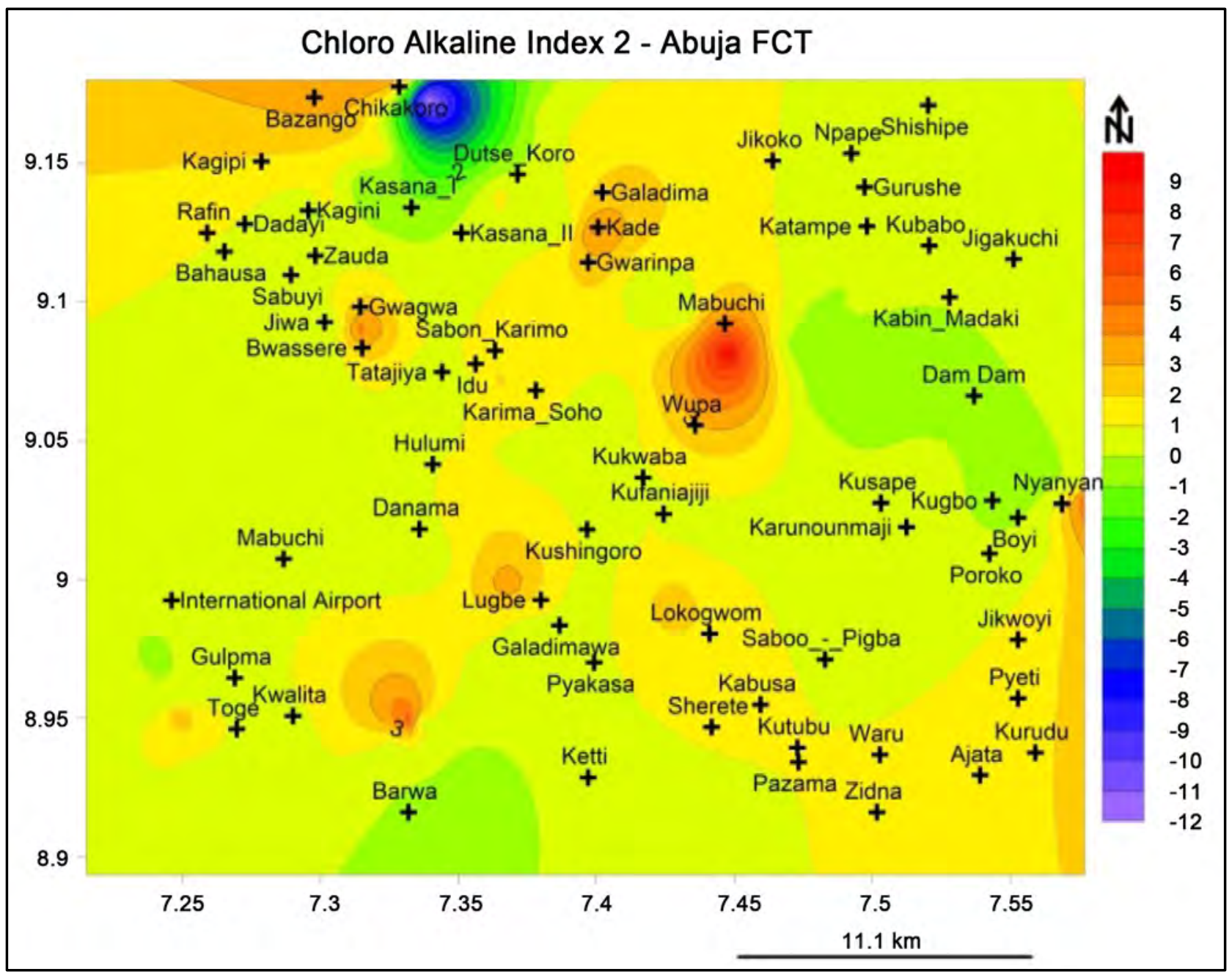

Figure 11. Spatial variation of Chloro alkaline index 2 in Abuja; $\mathrm{CAI}_{2}$ is maximum at Mabuchi, Wupa and Gwagwa whereas low values are at Chikakoro, Kabin Madaki, Dam Dam, Barwa and Duste.

The expression of the ionic relationships in terms of mathematical ratio is quite helpful for establishing the chemical similarities among water, representing a single geologic terrain or single aquifer $\left(\mathrm{Na}^{+} / \mathrm{Cl}^{-}\right)$. The collected samples have ratio ranging from 0 to 195.26 , and the increase is due to the impact of marine salts on the groundwater composition, dissolution, ion exchange process and also may attributed to the addition of sodium salts of terrestrial origin to the water.

Eighteen (18) ionic ratios in groundwater were used to deduce formation inputs in Abuja, as demonstrated in Table 5. Twelve (12) of the 18 ionic ratios calculated gave indices indicating weathering of geologic formations in Abuja as a source of solute concentration in the groundwater while nitrate ratio indicates no anthropogenic contribution and sulfate indices indicates no oxidation of sulfides. $\mathrm{Ca}$ is sourced from gypsum while $\mathrm{Na}$ is sourced from halite-albite and ion exchange. $\mathrm{Mg}$ is contributed by dolomite dissolution, calcite precipitation or saltwater and Seawater or brine or evaporates as discussed in [17]. 
Table 5. Ionic ratios with determined formation input.

\begin{tabular}{|c|c|c|c|}
\hline Ionic ratio & Range & Comment & Interpretation \\
\hline $\mathrm{SO}_{4} / \mathrm{Cl}$ & $0.00-0.36$ & High & Additional sources of $\mathrm{SO}_{4}$ from weathering of sulfates \\
\hline $\mathrm{Na} / \mathrm{Cl}$ & $0.01-1.32$ & High & Na-adsorption during freshening and a little silicate weathering \\
\hline $\mathrm{Mg} / \mathrm{Cl}$ & $0-1.29$ & High & Cation-exchange and silicate weathering of sandstones. \\
\hline $\mathrm{Na} / \mathrm{HCO}_{3}$ & $0.02-3.38$ & High & Substantial weathering of $\mathrm{Na}$-feldspar or other $\mathrm{Na}$-silicates \\
\hline $\mathrm{Ca} / \mathrm{HCO}_{3}$ & $0.00-11.1$ & High & Calc-carbonate dissolution or Calc-silicate weathering \\
\hline $\mathrm{Ca} / \mathrm{SO}_{4}$ & $0.00-75.2$ & High & Gypsum dissolution present \\
\hline $\mathrm{Ca} / \mathrm{Mg}$ & $0.00-144.67$ & High & Cation-exchange of weathering of silicate rocks. \\
\hline $\mathrm{Ca}+\mathrm{Mg} / \mathrm{Na}+\mathrm{K}$ & $0.00-10.25$ & High & Carbonate weathering \\
\hline $\mathrm{HCO}_{3} / \Sigma$ Anions & $0.04-0.91$ & High & Weathering reactions and input of dissolved species in recharge area \\
\hline $\mathrm{NO}_{3} / \Sigma$ Anions & $0.00-0.39$ & High & Anthropogenic contribution \\
\hline $\mathrm{SO}_{4} / \sum$ Anions & $0.00-0.09$ & Low & No oxidation of sulphides. \\
\hline $\mathrm{Mg} / \mathrm{Ca}$ & $0.00-2.44$ & Low & Weathering of Silicate rocks \\
\hline $\mathrm{Na} / \mathrm{Na}+\mathrm{Cl}$ & $0.01-0.57$ & High & Sodium source other than halite-albite, ion exchange \\
\hline $\mathrm{Mg} / \mathrm{Ca}+\mathrm{Mg}$ & $0.00-0.71$ & High & Dolomite dissolution, calcite precipitation or saltwater \\
\hline $\mathrm{Ca} / \mathrm{Ca}+\mathrm{SO}_{4}$ & $0.00-1.00$ & High & Calcium source other than gypsum \\
\hline $\mathrm{Ca}+\mathrm{Mg} / \mathrm{SO}_{4}$ & $0.00-195.26$ & High & \\
\hline $\mathrm{Na}+\mathrm{K}-\mathrm{Cl} / \mathrm{Na}+\mathrm{K}-\mathrm{Cl}+\mathrm{Ca}$ & $-4.39-112.22$ & High & Plagioclase weathering unlikely \\
\hline $\mathrm{Cl} / \Sigma$ Anions & $0.08-0.93$ & High & Seawater or brine or evaporates \\
\hline
\end{tabular}

\subsection{Gibb's Diagram}

To know the groundwater chemistry and the relationship of the chemical components of the groundwater to their respective aquifers; chemistry of the rock types, the chemistry of precipitated water, and the rate of evaporation, according to [24] diagram in which the ratio of dominant anions and cations are plotted against the value of TDS was done. The chemical data of the collected groundwater samples are plotted in the Gibbs diagram as seen in Figure 12. Ninety-five (95) percent of the groundwater chemistry is a result of chemical weathering of rock-forming minerals through the dissolution of the host rock. Four percent of the groundwater chemistry results from atmospheric precipitation. One percent of the groundwater chemistry results from evaporation and recrystallization of minerals in the aquifer Table 6.

\subsubsection{Atmospheric (Rainfall) Precipitation Dominance (4\%)}

Aquifers that receive rainwater without much influence by rock weathering (due to short residence times in hard rocks, well-drained-high-porosity formations and/or high hydraulic gradients) contain groundwater with low concentrations of ions. Rainwater is a dilute solution of carbonic acid with an admixture of a small amount of sea salt. Because of the source of atmospheric ions (from sea spray), chloride and sodium are relatively more abundant than the other ions in 


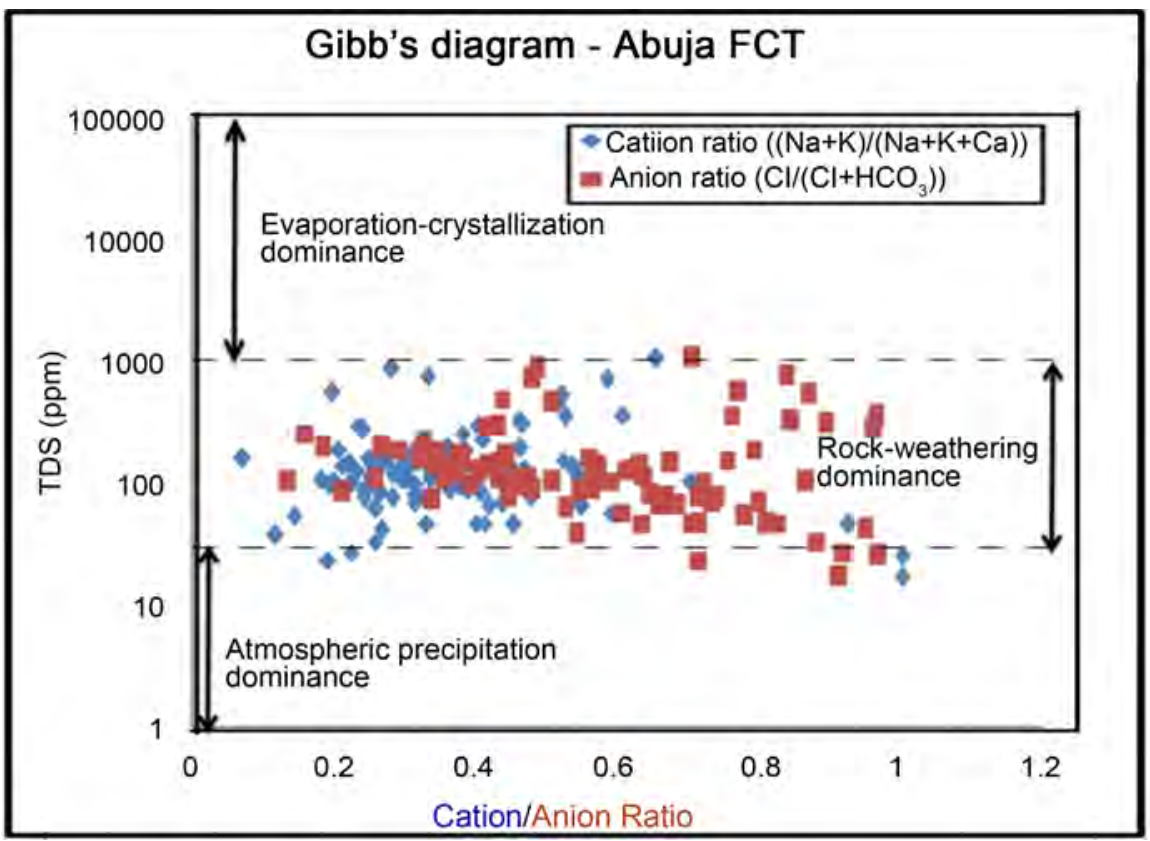

Figure 12. Gibbs diagram for sources of ionic content in Abuja [24]: 94.86\% of the samples plot in the rock-weathering dominance $1.06 \%$ fall in Evaporation-Crystallization dominance field and $4.26 \%$ fall in the Atmospheric precipitation dominance field.

Table 6. Gibbs classification of groundwater in Abuja [24].

\begin{tabular}{lcc}
\hline \multicolumn{1}{c}{ Groundwater/rock interaction/evolution } & (Gibbs diagram)-Abuja & FCT \\
\hline \multicolumn{1}{c}{ Ionic character } & Samples & $\%$ \\
\hline Cations & 4 & \\
Atmospheric precipitation dominance & 89 & 4.3 \\
Rock-weathering dominance & 1 & 94.5 \\
Evaporation-crystallization dominance & & 0.9 \\
Anions & 4 & \\
Atmospheric precipitation dominance & 89 & 4.3 \\
Rock-weathering dominance & 1 & 94.5 \\
Evaporation-crystallization & & 0.9 \\
\hline
\end{tabular}

rainwater. The relative abundance of salts is not precisely the same as seawater because there is some fractionation during evaporation and transport of sea salts and rainwater is in equilibrium with atmospheric $\mathrm{CO}_{2}$.

\subsubsection{Rock Weathering (Host Rock) Dominance (95\%)}

In general, weathering reactions can be characterized as a weak acid (carbonic acid) slowly dissolving basic minerals. Weathering reactions result in groundwater containing dissolved ions, and commonly, un-dissolved particles of less soluble minerals such as clays. Groundwater in such an environment over time becomes more or less in equilibrium with the weathering aquiferous formation and is characterized by higher concentrations of ions and an increased signific- 
ance of $\mathrm{Ca}, \mathrm{Mg}$, and bicarbonate ions. Many African basement aquifers contain groundwater which can be characterized as rock weathering-dominated as discussed in [25] [26] [27].

The possible processes in gneissic/granitic weathering could take the following pathways, Equations $1-6$ through hydrolysis, carbonization and solution as discussed in [17].

$$
\mathrm{NaAlSi}_{3} \mathrm{O}_{8}+\mathrm{H}_{2} \mathrm{CO}_{3}+4.5 \mathrm{H}_{2} \mathrm{O}=\mathrm{Al}_{2} \mathrm{Si}_{2} \mathrm{O}_{5}(\mathrm{OH})_{4}+\mathrm{Na}^{+}+\mathrm{HCO}_{3}^{-}+2 \mathrm{H}_{4} \mathrm{SiO}_{4}
$$

Albite + Hydrogen ions + water $=$ Kaolinite $($ clay $)+$ Sodium ions + silicic acid

$$
2 \mathrm{NaAlSi}_{3} \mathrm{O}_{8}+4 \mathrm{H}^{+}+4 \mathrm{H}_{2} \mathrm{O}=\mathrm{Al}^{3+}+\mathrm{Na}^{+}+2 \mathrm{H}_{4} \mathrm{SiO}_{4}
$$

Albite + Hydrogen ions + water $=$ Aluminum ions + Sodium ions + silicic acid

$$
2 \mathrm{KAlSi}_{3} \mathrm{O}_{8}+2\left(\mathrm{H}^{+}+\mathrm{HCO}_{3}^{-}\right)+\mathrm{H}_{2} \mathrm{O}=\mathrm{Al}_{2} \mathrm{Si}_{2} \mathrm{O}_{5}(\mathrm{OH})_{4}+2 \mathrm{~K}^{+}+2 \mathrm{HCO}_{3}^{-}+4 \mathrm{SiO}_{2}
$$

Orthoclase + Carbonic acid + water $=$ Kaolinite (clay) + Potassium ions + Bi carbonate + silica

$$
2 \mathrm{KAlSi}_{3} \mathrm{O}_{8}+2 \mathrm{H}^{+}+\mathrm{H}_{2} \mathrm{O}=\mathrm{Al}_{2} \mathrm{Si}_{2} \mathrm{O}_{5}(\mathrm{OH})_{4}+2 \mathrm{~K}^{+}+4 \mathrm{SiO}_{2}
$$

Orthoclase + Hydrogen ions + water $=$ Kaolinite $($ clay $)+$ Potassium ions + silica Orthoclase:

$$
2 \mathrm{KAlSi}_{3} \mathrm{O}_{8}+11 \mathrm{H}_{2} \mathrm{O}=\mathrm{Al}_{2} \mathrm{Si}_{2} \mathrm{O}_{5}(\mathrm{OH})_{4}+\mathrm{Si}(\mathrm{OH})_{4}+2 \mathrm{~K}^{+}+2 \mathrm{OH}^{-}
$$

Biotite + water $=$ Aluminum ions + Iron ions + Kaolinite (clay)

$$
\mathrm{KMg}_{2} \mathrm{FeAlSi}_{3} \mathrm{O}_{10}(\mathrm{OH})_{2}+\mathrm{H}_{2} \mathrm{O}=\mathrm{Al}^{+} \mathrm{Si}+\mathrm{Fe}^{2+}+\mathrm{Fe}^{3+}+\mathrm{Al}_{2} \mathrm{Si}_{2} \mathrm{O}_{5}(\mathrm{OH})_{4}
$$

The leached cations may then enrich the percolating groundwater, giving it its ionic character.

\subsubsection{Evaporation-Precipitation Dominance (1\%)}

Evaporation and fractional precipitation represent the third mechanism in the influence of geology on groundwater. In tropical and sub-tropical zones with high temperatures, rainfall, porosity and where the phreatic aquiferous formation is thin and porous, or shallow fractures prevail, the overall concentration of ions increases in the formation with evaporation until selected minerals begin to precipitate because their solubility product have been exceeded. Since $\mathrm{CaCO}_{3}$ is commonly the first mineral to precipitate, the relative concentration of these ions begins to decline with evaporation. With further evaporation, other minerals, such as gypsum $\left(\mathrm{CaSO}_{4}\right)$ will also precipitate. As a consequence, the relative concentrations of $\mathrm{Na}^{+}, \mathrm{K}^{+}$, and $\mathrm{Cl}^{-}$in the groundwater will increase.

\subsection{Piper's Diagram}

The concept of hydrogeochemical facies was developed in order to understand, identify and classify water composition in different classes as discussed in [17] [28]. Facies are recognizable distinct zones that possess cation and anion concentration categories belonging to any genetically related system with. Accord- 
ing to [29] Piper diagram is one of many trilinear diagrams used to infer hydrogeochemical facies. It consists of three fields in a large triangle; two smaller triangular fields, one for plotting cations and another for plotting anions, are projected unto the third larger diamond shaped field, from which inference is drawn on the basis of hydrogeochemical facies concept. This tri-linear diagram is useful in bringing out chemical relationships among the groundwater samples in more definite terms rather than with any other possible plotting methods. A piper diagram was generated for the study area using the analytical data obtained from the hydrogeochemical analysis of the ninety-four groundwater samples as seen in Figure 13. This diagram revealed the dissimilarities and analogies in the different class types of water in the study area, which are identified and demonstrated in Table 7.

\subsection{Groundwater Types}

The diamond field of Piper's diagram has seven classes A-G classifying water types and designated with alphabets from $A$ to $G$ as seen in Figure 13. Water from Abuja falls into A, B, D, E and G categories Table 8 and there is no category F. Category A 9 samples has $9.6 \%$ of samples; which indicates bicarbonate as prevailing ion of groundwater. Category B; 18 samples; $19.14 \%$ are characterized by normal earth alkaline water with prevailing bicarbonate. Category C; 15 samples, $15.95 \%$ are characterized by alkaline earth water with increased portions of alkalis with prevailing bicarbonate. Category D; 19 samples, 31.91\%; are characterized by earth alkaline water with prevailing $\mathrm{HCO}_{3}^{-}$; Category E; 30 samples, 20.21\%; are characterized by earth alkaline water with added portions of alkalis with prevailing chloride and Category G; 3 samples, 3.19\%; are characterized by alkaline water with prevailing sulfate or chloride. Groundwater in $\mathrm{Ab}$ uja is made up of 2 major water types; $\mathrm{MgHCO}_{3}$ and $\mathrm{CaHCO}_{3}$ as demonstrated in Table 6.

\subsection{Piper's Hydrogeochemical Facies}

From the Piper's diagram Figure 13, groundwater in Abuja is characterized by three hydrogeochemical facies. Field (I): Ca- $\mathrm{Mg}-\mathrm{Cl}-\mathrm{SO}_{4}$ hydrogeochemical facies, 51 samples $54.25 \%$, this facies are characteristic of groundwater some distance along its flow paths Field (II) Na-K-Cl- $-\mathrm{SO}_{4}$ hydrogeochemical facies has 40 samples, $3.19 \%$ and Field (IV) $\mathrm{Ca}-\mathrm{Mg}-\mathrm{HCO}_{3}$ hydrogeochemical facie has 40 samples, $42.56 \%$, this facies is characteristic of freshly recharged groundwater that has equilibrated with $\mathrm{CO}_{2}$ and soluble carbonate minerals under an open system conditions in the vadose zone typical of shallow groundwater flow systems in crystalline phreatic aquifers. No samples plotted on Field III. The high contribution of alkaline earth elements in all seasons is due to direct ion-exchange processes which enriched groundwater with alkaline earth elements.

\subsection{Durov Diagram}

For better understanding the hydrochemistry and comparing the water types, 


\section{Piper Diagram, Abuja FCT}
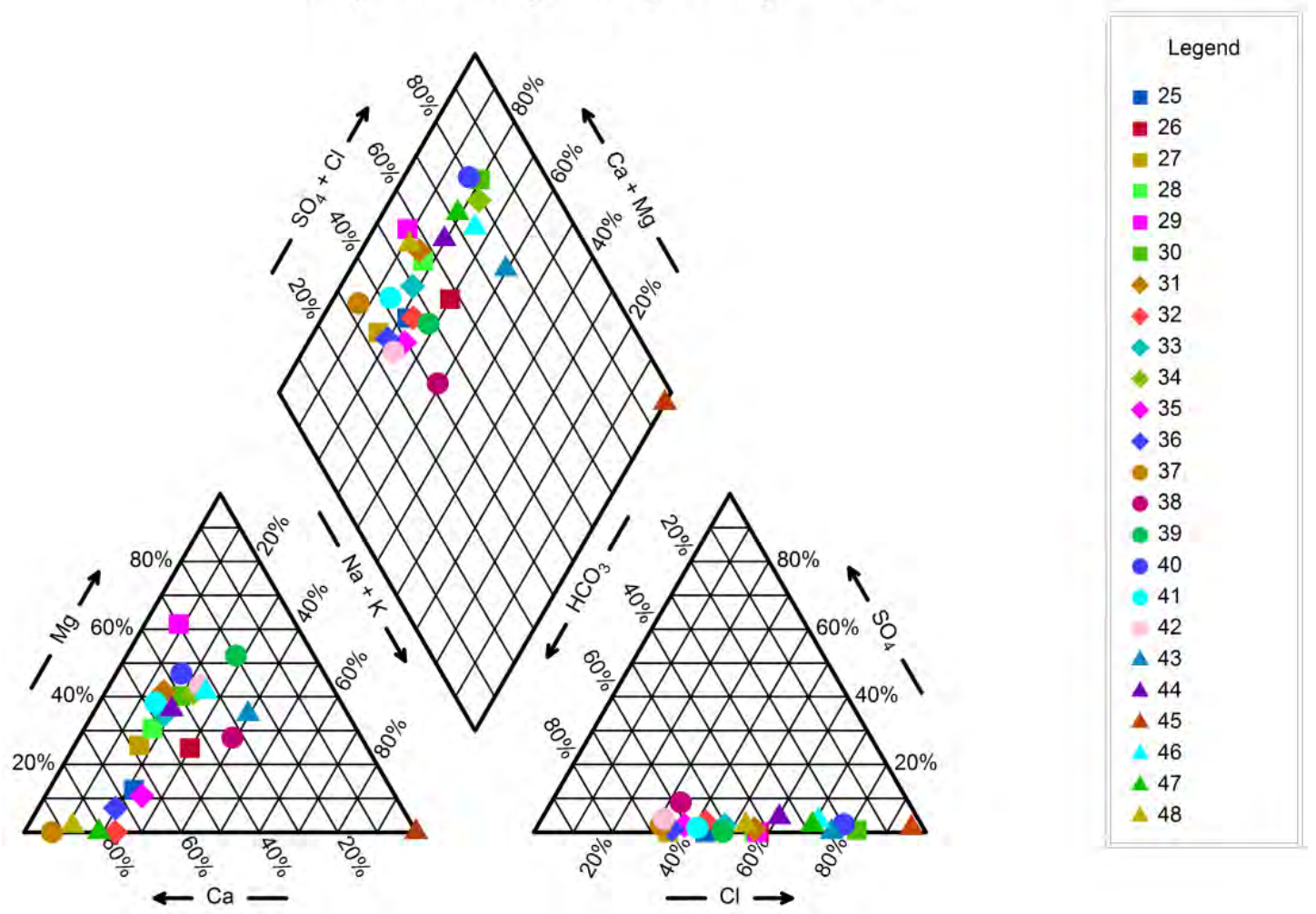

(a)
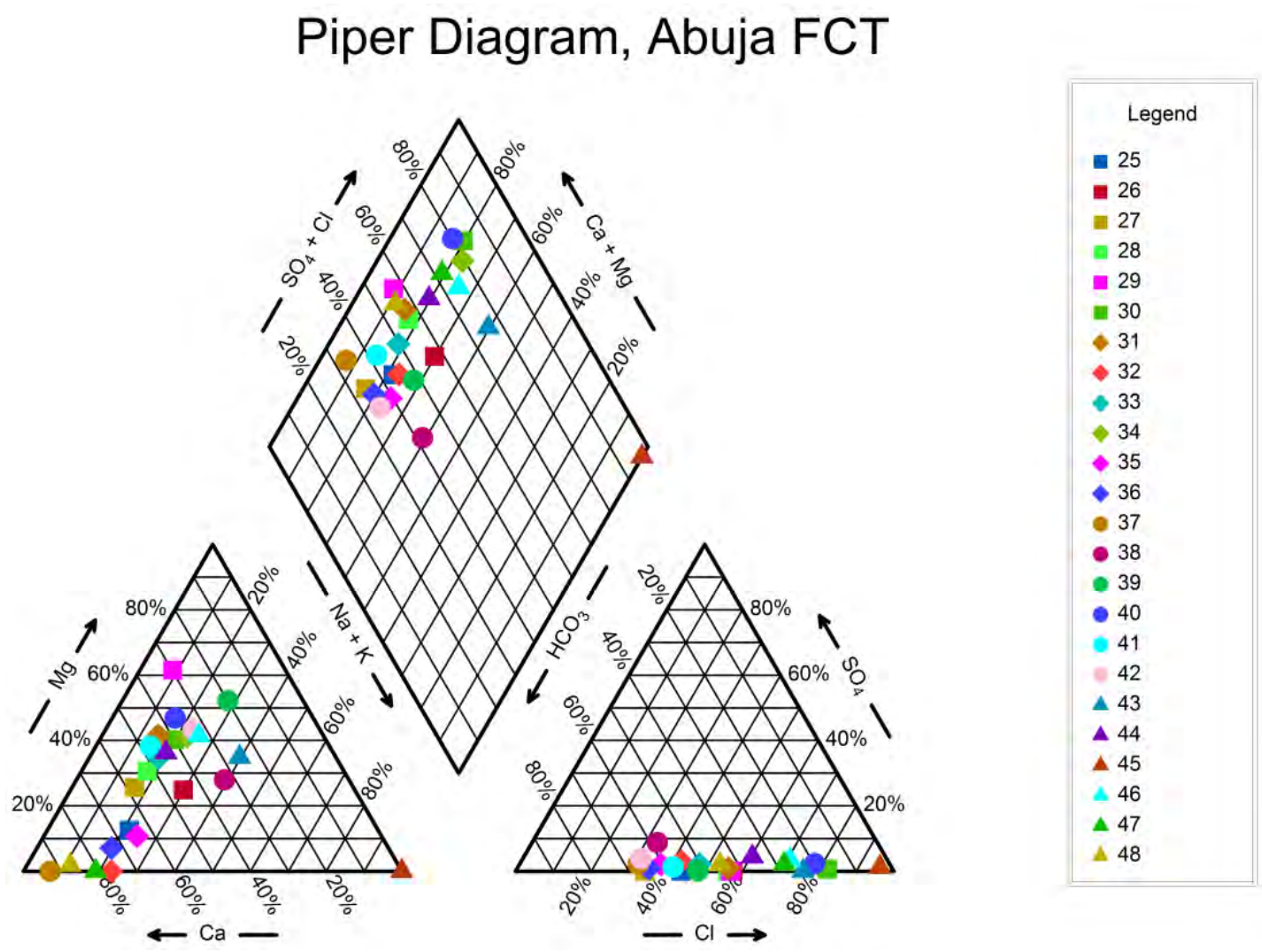

(b) 


\section{Piper Diagram, Abuja FCT}

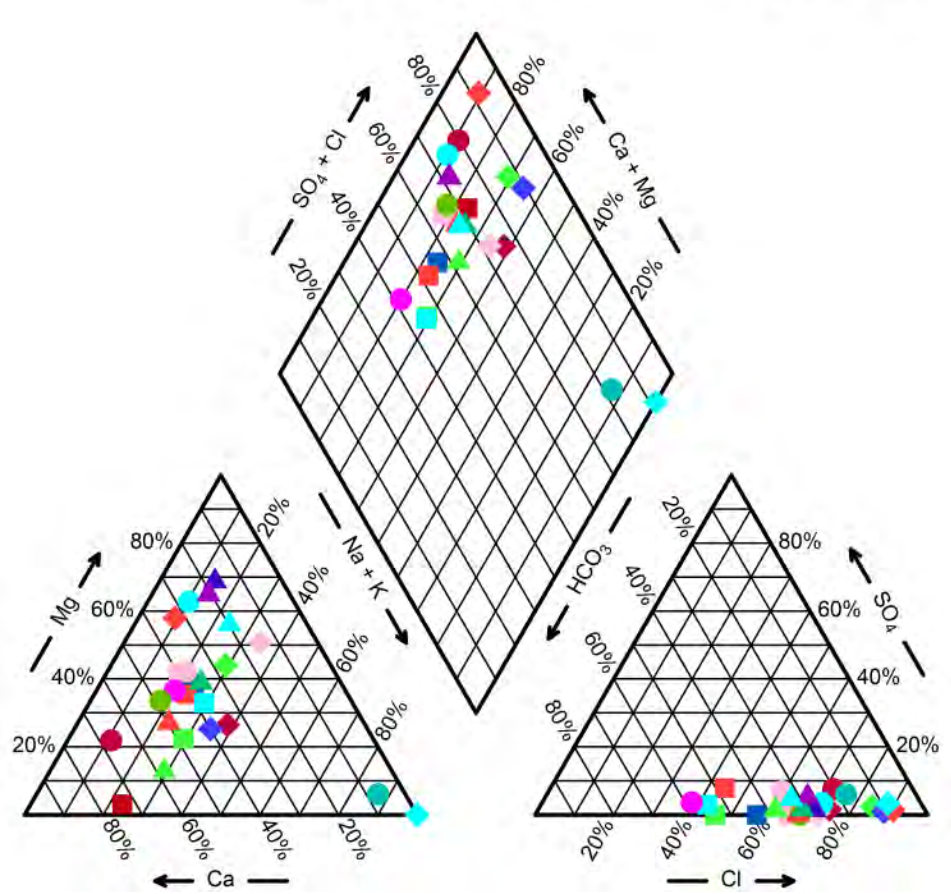

(c)

\begin{tabular}{|c|}
\hline Legend \\
\hline$=49$ \\
\hline 50 \\
\hline E 51 \\
\hline = 52 \\
\hline$=53$ \\
\hline$=54$ \\
\hline$\diamond 55$ \\
\hline$\geqslant 56$ \\
\hline$\diamond 57$ \\
\hline 58 \\
\hline$\bullet 59$ \\
\hline+60 \\
\hline - 61 \\
\hline 62 \\
\hline 63 \\
\hline 64 \\
\hline - 65 \\
\hline 66 \\
\hline A 67 \\
\hline$\Delta 68$ \\
\hline$\Delta 69$ \\
\hline$\Delta 70$ \\
\hline A 71 \\
\hline A 72 \\
\hline
\end{tabular}

\section{Piper Diagram, Abuja FCT}
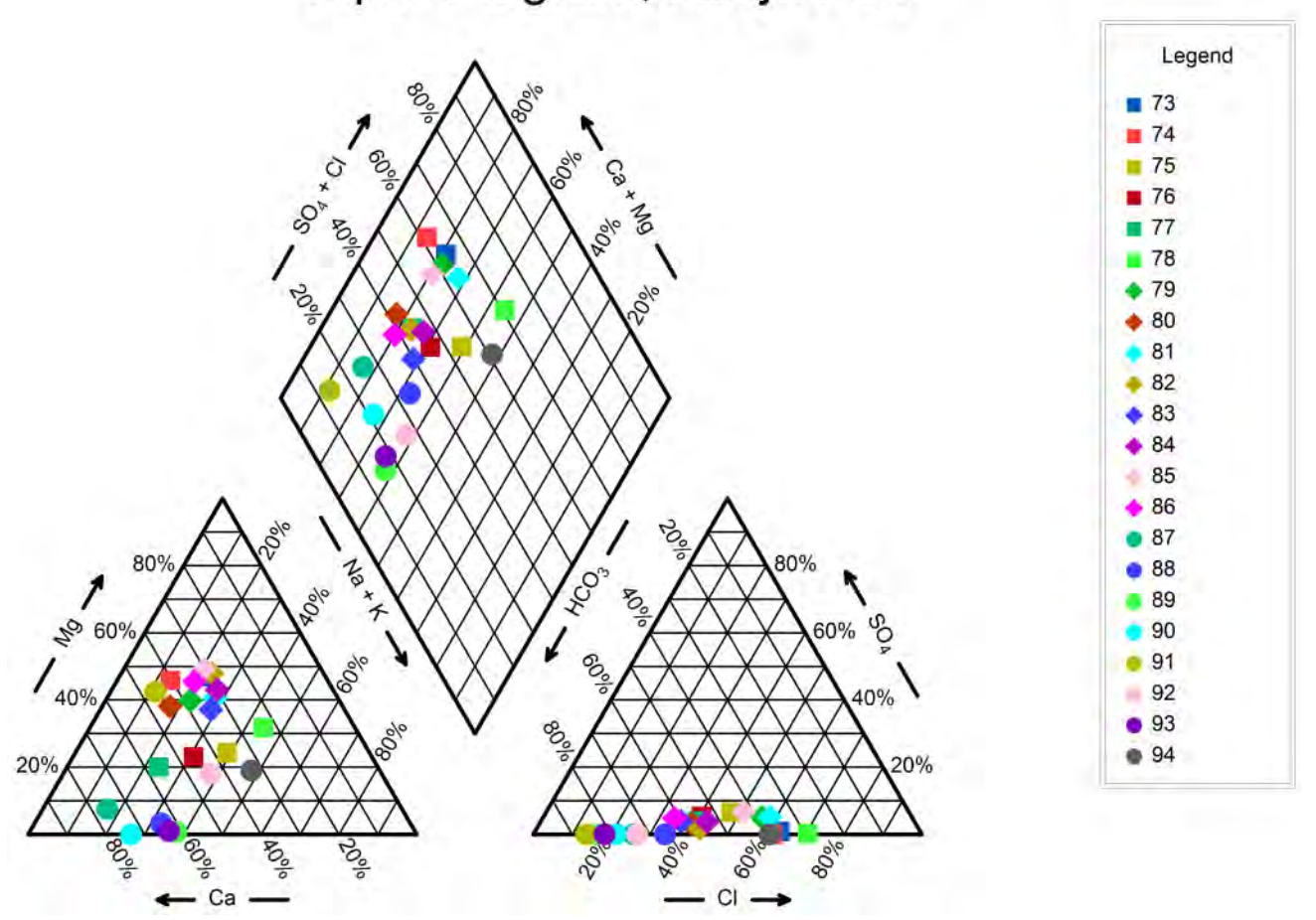

(d)

Figure 13. Piper's diagram for Abuja groundwater with three hydrogeochemical facies in Abuja; Field (I): Ca-Mg-Cl-SO $\mathrm{S}_{4}$ hydrogeochemical facies, 51 samples $54.25 \%$, Field (II): $\mathrm{Na}-\mathrm{Mg}-\mathrm{Cl}-\mathrm{SO}_{4}$ hydrogeochemical facies, 3 samples $3.19 \%$. This facies is characteristic of stagnant groundwater zones. Field (IV), Ca-Mg- $\mathrm{HCO}_{3}$ hydrogeochemical facies has 40 samples, $42.56 \%$. 
Table 7. Classification of Abuja groundwater based on Piper diagram [18] to depict water types and hydrogeochemical facies.

\begin{tabular}{|c|c|c|c|}
\hline Class & Water types & No & $\%$ \\
\hline A & Normal earth alkaline water with prevailing bicarbonate & 9 & 9.60 \\
\hline $\mathrm{B}$ & $\begin{array}{l}\text { Normal earth alkaline water with prevailing bicarbonate } \\
\text { and sulfate or chloride }\end{array}$ & 18 & 19.14 \\
\hline $\mathrm{C}$ & $\begin{array}{l}\text { Normal earth alkaline water with prevailing Sulfate or } \\
\text { Chloride }\end{array}$ & 15 & 15.95 \\
\hline $\mathrm{D}$ & $\begin{array}{l}\text { Earth alkaline water; increased portions of alkalis; } \\
\text { prevailing } \mathrm{HCO}_{3}^{-}\end{array}$ & 19 & 20.21 \\
\hline $\mathrm{E}$ & $\begin{array}{l}\text { Earth alkaline water with added portions of alkalis with } \\
\text { prevailing chloride }\end{array}$ & 30 & 31.91 \\
\hline G & Alkaline water with prevailing sulfate or chloride & 3 & 3.19 \\
\hline \multicolumn{4}{|c|}{ Cations field } \\
\hline 1 & Calcium rich & 71 & 75.53 \\
\hline 2 & Magnesium rich & 20 & 21.28 \\
\hline 3 & Sodium + Potassium rich & 3 & 3.19 \\
\hline \multicolumn{4}{|c|}{ Anion Field } \\
\hline 4 & Bicarbonate rich & 46 & 48.94 \\
\hline 5 & Chloride rich & 48 & 51.06 \\
\hline \multicolumn{4}{|c|}{ Hydrogeochemical facies } \\
\hline Field I & $\mathrm{Ca}-\mathrm{Mg}-\mathrm{Cl}-\mathrm{SO}_{4}$ & 51 & 54.25 \\
\hline Field II & $\mathrm{Na}-\mathrm{K}-\mathrm{Cl}-\mathrm{SO}_{4}$ & 3 & 3.19 \\
\hline Field IV & $\mathrm{Ca}-\mathrm{Mg}-\mathrm{HCO}_{3}$ & 40 & 42.56 \\
\hline
\end{tabular}

Table 8. Classification of water based on Durov diagram.

\begin{tabular}{|c|c|c|c|}
\hline SN & Description of Water Types & No & $\%$ \\
\hline 1 & $\begin{array}{l}\mathrm{HCO}_{3} \text { and } \mathrm{Ca} \text { dominant, frequently indicates recharging waters in } \\
\text { limestone, sandstone, and many other aquifers }\end{array}$ & 3 & 3.19 \\
\hline 2 & $\begin{array}{l}\text { This water type is dominated by } \mathrm{Ca} \text { and } \mathrm{HCO}_{3} \text { ions. Association with } \\
\text { dolomite is presumed if } \mathrm{Mg} \text { is significant. However, those samples in } \\
\text { which } \mathrm{Na} \text { is significant, an important ion exchanged is presumed }\end{array}$ & 1 & 1.06 \\
\hline 3 & $\begin{array}{l}\mathrm{HCO}_{3} \text { and } \mathrm{Na} \text { are dominant, normally indicates ion exchanged water, } \\
\text { although the generation of } \mathrm{CO}_{2} \text { at depth can produce } \mathrm{HCO}_{3} \text { where } \mathrm{Na} \\
\text { is dominant under certain circumstances }\end{array}$ & 2 & 2.13 \\
\hline 4 & $\begin{array}{l}\mathrm{SO}_{4} \text { dominates, or anion discriminate and Ca dominant; mixed water or } \\
\text { water exhibiting simple dissolution may be indicated }\end{array}$ & 19 & 20.21 \\
\hline 5 & $\begin{array}{l}\text { No dominant anion or cation, indicates water exhibiting simple } \\
\text { dissolution or mixing }\end{array}$ & 60 & 63.83 \\
\hline 6 & $\begin{array}{l}\mathrm{SO}_{4} \text { dominant or anion discriminate and } \mathrm{Na} \text { dominant; is water type that } \\
\text { is not frequently encountered and indicates probable mixing or } \\
\text { uncommon dissolution influences }\end{array}$ & 6 & 6.38 \\
\hline 7 & $\begin{array}{l}\mathrm{Cl} \text { and } \mathrm{Na} \text { dominant are frequently encountered or the water may have } \\
\text { resulted from reverse ion exchange of } \mathrm{Na}-\mathrm{Cl}\end{array}$ & 3 & 3.19 \\
\hline
\end{tabular}


Durov Diagram was plotted as seen in Figure 14. The 9 fields of the Durov diagram on which the samples fall is given in below.

\section{Durov Diagram, Abuja FCT}

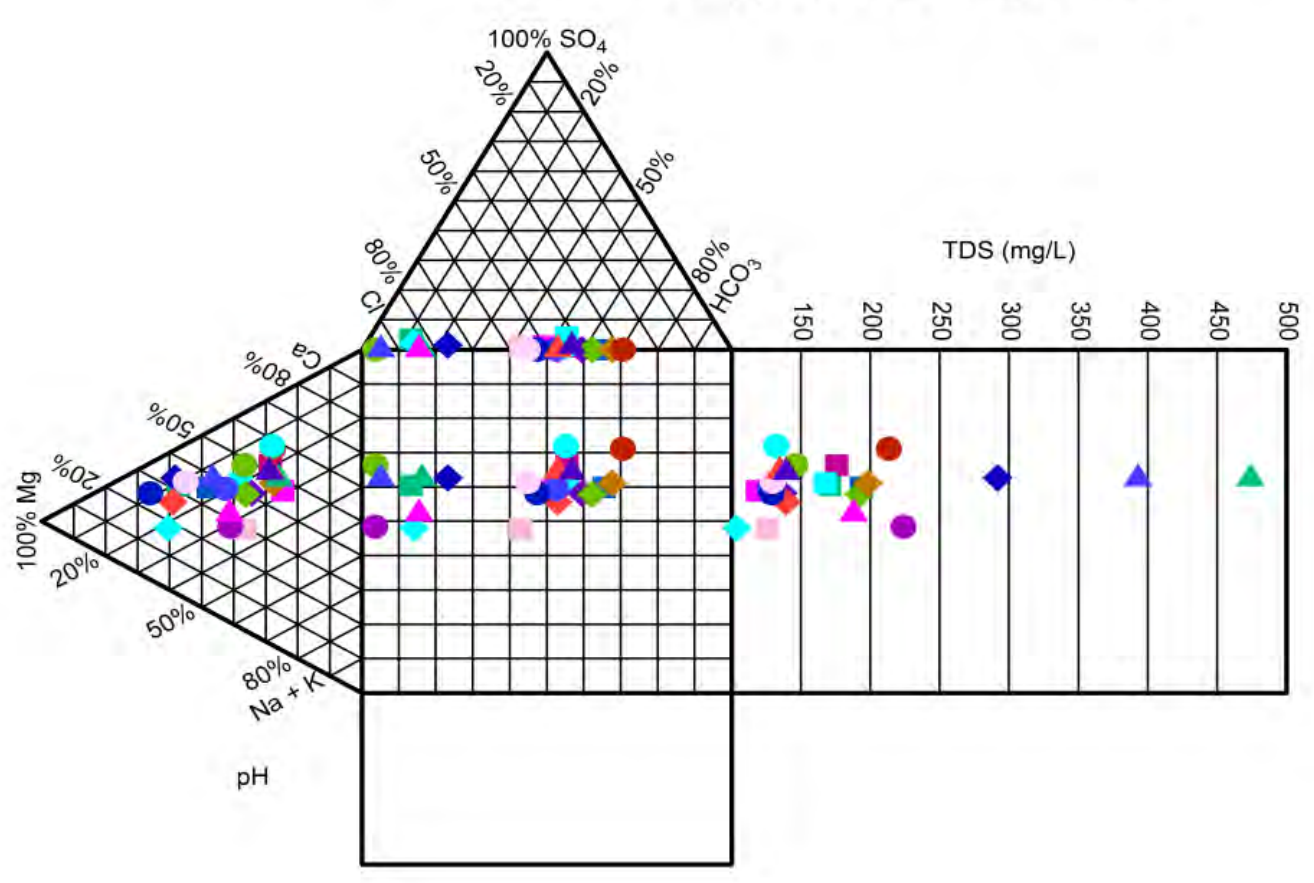

(a)

\section{Durov Diagram, Abuja FCT}

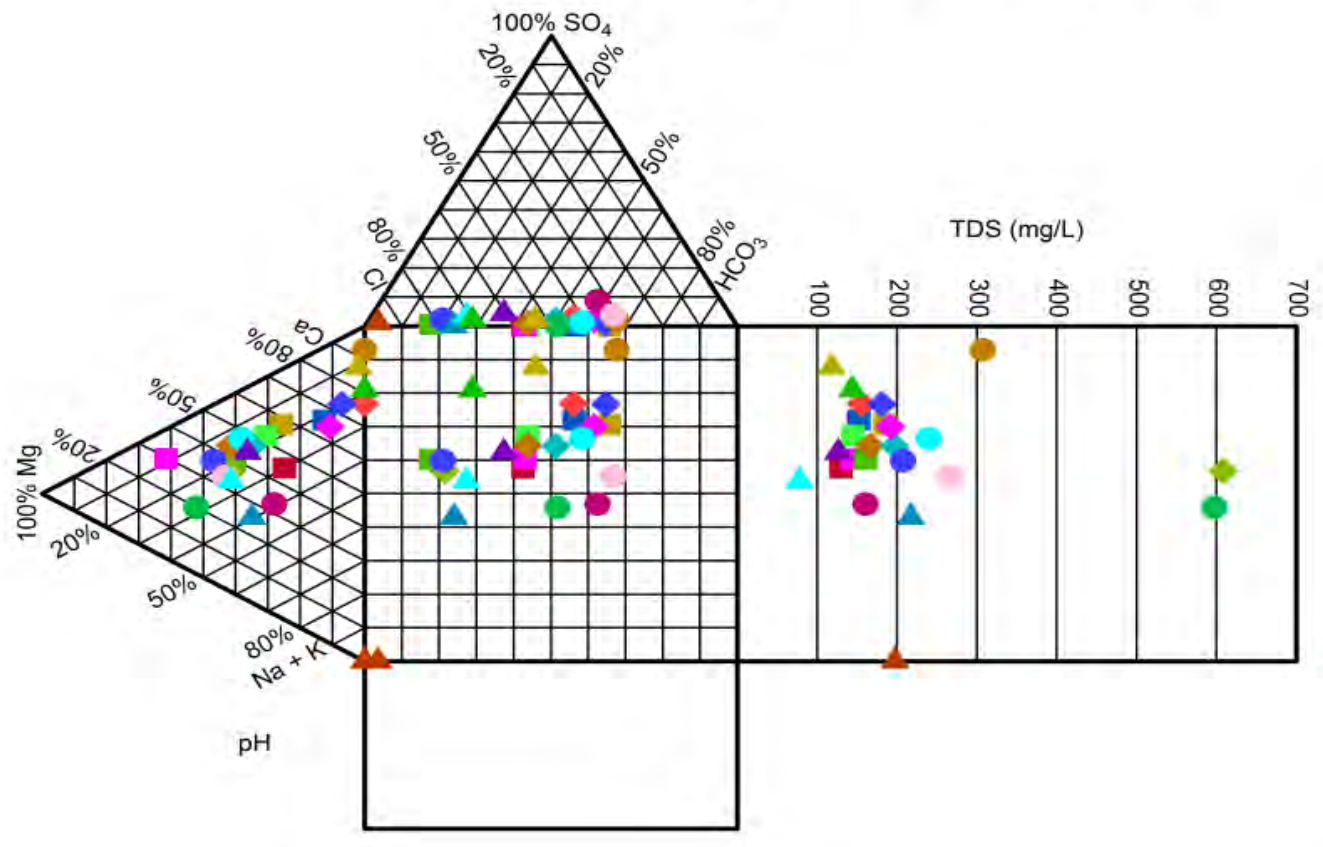

(b) 


\section{Durov Diagram, Abuja FCT}

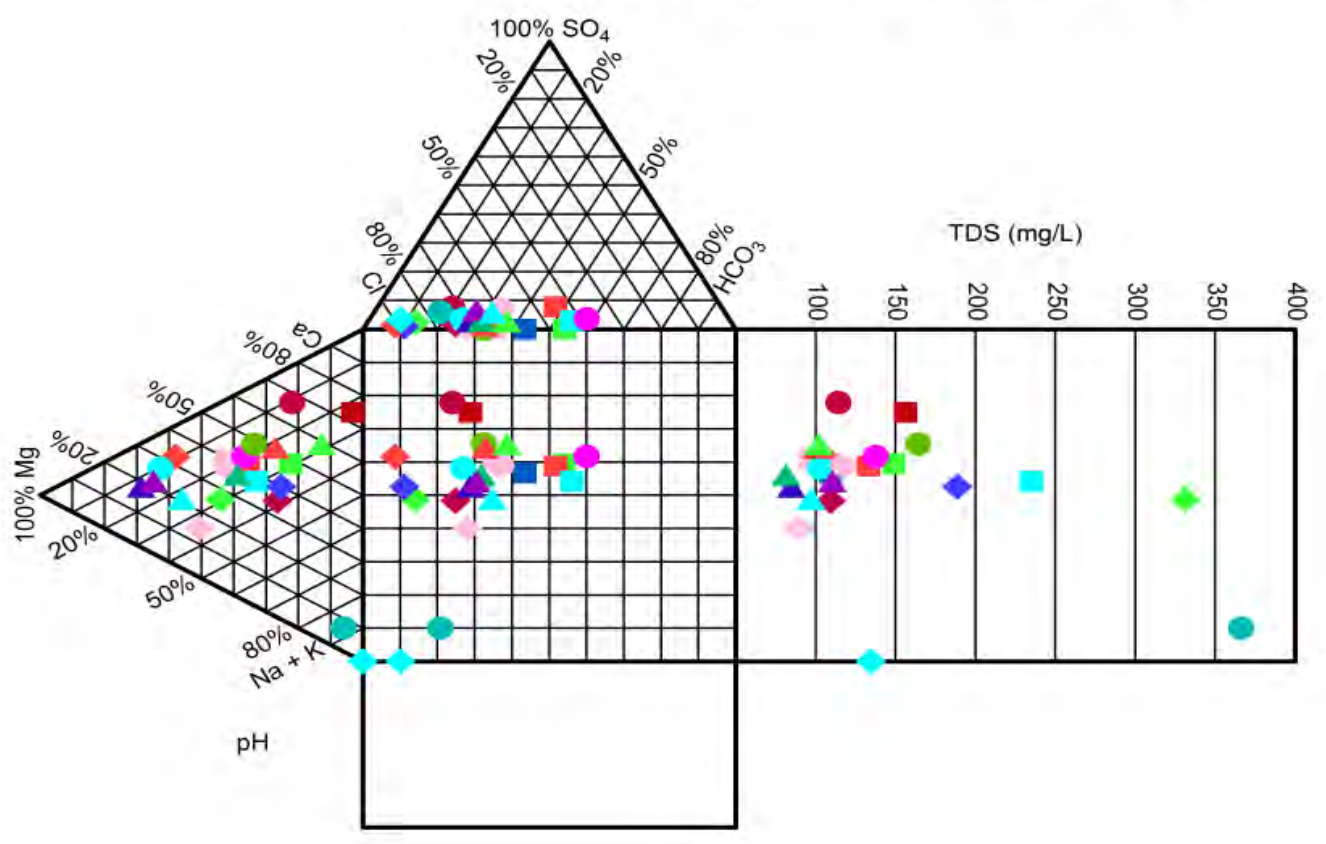

\begin{tabular}{|c|}
\hline Legend \\
\hline = 49 \\
\hline$=50$ \\
\hline$=51$ \\
\hline च 52 \\
\hline$=53$ \\
\hline 54 \\
\hline$\bullet 55$ \\
\hline+56 \\
\hline \$ 57 \\
\hline 48 \\
\hline$\star 59$ \\
\hline+60 \\
\hline - 61 \\
\hline 62 \\
\hline 63 \\
\hline$=64$ \\
\hline - 65 \\
\hline 66 \\
\hline$\Delta 67$ \\
\hline$\triangle 68$ \\
\hline$\triangle 69$ \\
\hline$\Delta 70$ \\
\hline$\triangle 71$ \\
\hline$\perp 72$ \\
\hline
\end{tabular}

(c)

\section{Durov Diagram, Abuja FCT}

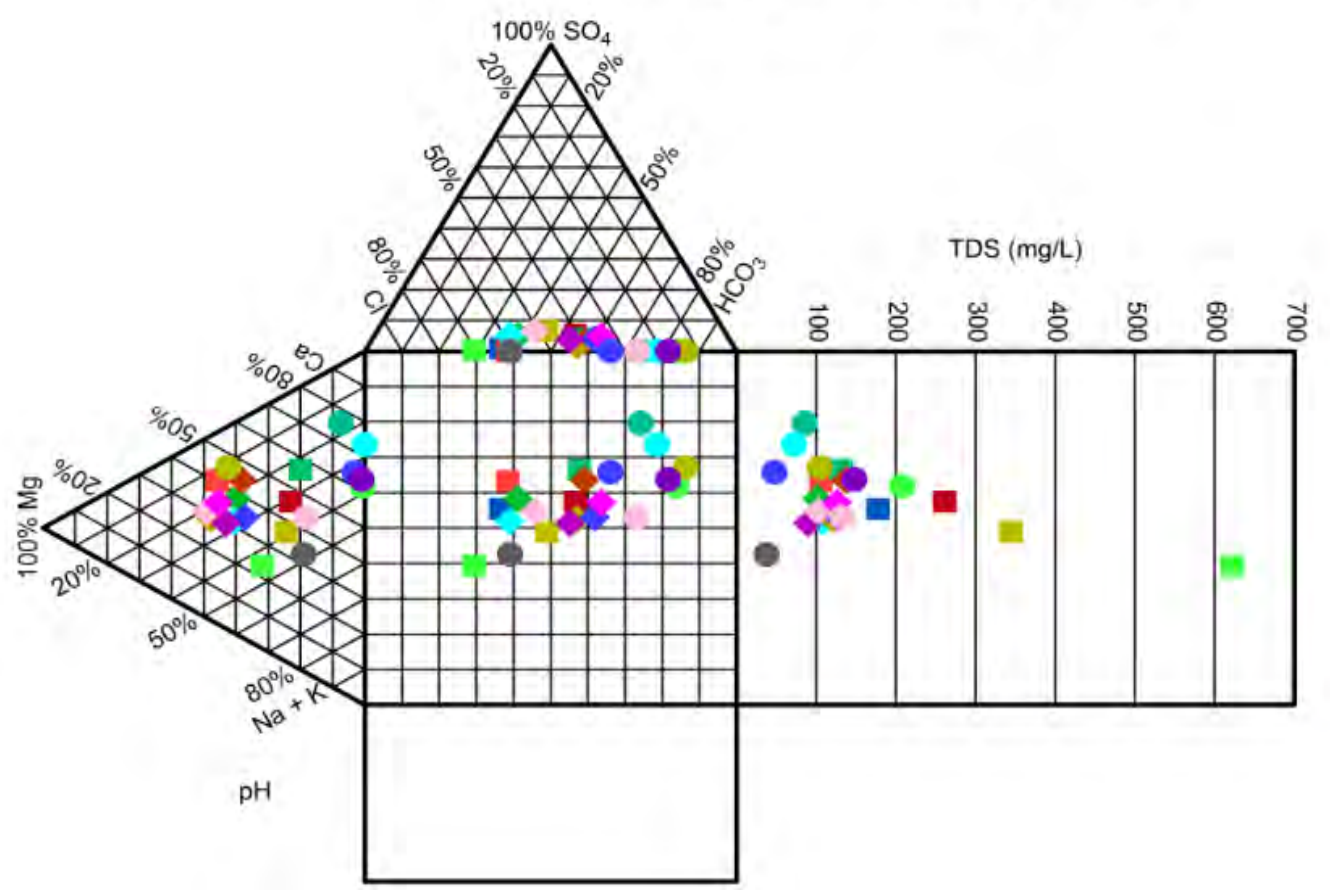

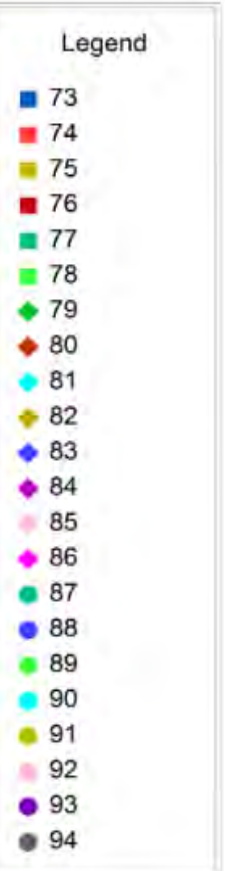

(d)

Figure 14. Durov plot of Abuja groundwater to depict the processes in groundwater evolution; Class 1 recharging waters: 3 samples, 3.19\%; Class 2 ion exchange water: 1 sample, 1.06\%; Class 3 ion exchange water: 2 samples, 2.13\%, Class 4 simple dissolution: 19 samples, 20.21\%; Class 5 simple dissolution or mixing: 60 samples, 63.83\%; Class 6 probable mixing or uncommon dissolution influences: 6 samples, $6.38 \%$; Class $7 \mathrm{Cl}$ and $\mathrm{Na}$ dominant is frequently encountered: 3 samples, $3.19 \%$ respectively. 


\subsection{Hydrogeochemical Character of Abuja Groundwater}

According to [30] Durov diagram is a composite plot consisting of two ternary diagrams where the milliequivalent percentages of cations are plotted perpendicularly against those of anions; the sides of the triangles form a central rectangular binary plot of total cation vs. total anion concentrations. These are divided into nine Classes which give the hydrogeochemical processes determining the character of the water types in the aquiferous formation as discussed in [19]. Based on this Classification Table 7; seven Classes occur in the study area; Class 1 recharging waters: 3 samples, 3.19\%; Class 2 ion exchange water: 1 sample, 1.06\%; Class 3 ion exchange water: 2 samples, 2.13\%, Class 4 simple dissolution: 19 samples, 20.21\%; Class 5 simple dissolution or mixing: 60 samples, $63.83 \%$; Class 6 probable mixing or uncommon dissolution influences: 6 samples, $6.38 \%$; Class $7 \mathrm{Cl}$ and $\mathrm{Na}$ dominant is frequently encountered: 3 samples, $3.19 \%$ respectively as demonstrated in Table 8 . There are no Classes 8 and 9 in the groundwater from Abuja FCT.

Dominance of $\mathrm{Ca}$ and $\mathrm{Mg}$ in the groundwater samples collected from the high topography suggested an inverse ion exchange process. During this process $\mathrm{Ca}$ from the aquifer matrix will be exchanged by $\mathrm{Na}$ from the groundwater. However, in the lower topographic region water is dominated by the $\mathrm{Na}$ and $\mathrm{Cl}$ ions, which is represented by the discharge zone. Sluggish flow in these relatively flat regions enables sufficient rock-water interactions.

\section{Water Quality for Domestic Use}

\subsection{Water Quality Index (WQI) for Domestic Use}

Using [31] guideline values of ions present in the groundwater, WQI values were determined according to [32]. WQI values ranged from -220 - 180. Groundwater in Abuja is excellent-unsuitable for domestic purpose base on WQI as demonstrated in Table 9 and seen in Figure 15.

\subsection{Total Hardness $\left(\mathrm{H}_{\mathrm{T}}\right)$}

Total hardness values ranged from: 0 - 519.12 as seen in Figure 16. This is indicative that groundwater in Abuja is of soft, hard moderately hard and hard categories as demonstrated in Table 10.

Table 9. Water quality index classification of groundwater samples in Abuja.

\begin{tabular}{cccc}
\hline Index & Quality & WQI & $\%$ \\
\hline $0-25$ & Excellent & 51 & 54.26 \\
$26-50$ & Good & 14 & 14.89 \\
$51-75$ & Poor & 12 & 12.77 \\
$76-100$ & Very poor & 7 & 7.45 \\
$>100$ & Unsuitable & 10 & 10.64 \\
\hline
\end{tabular}




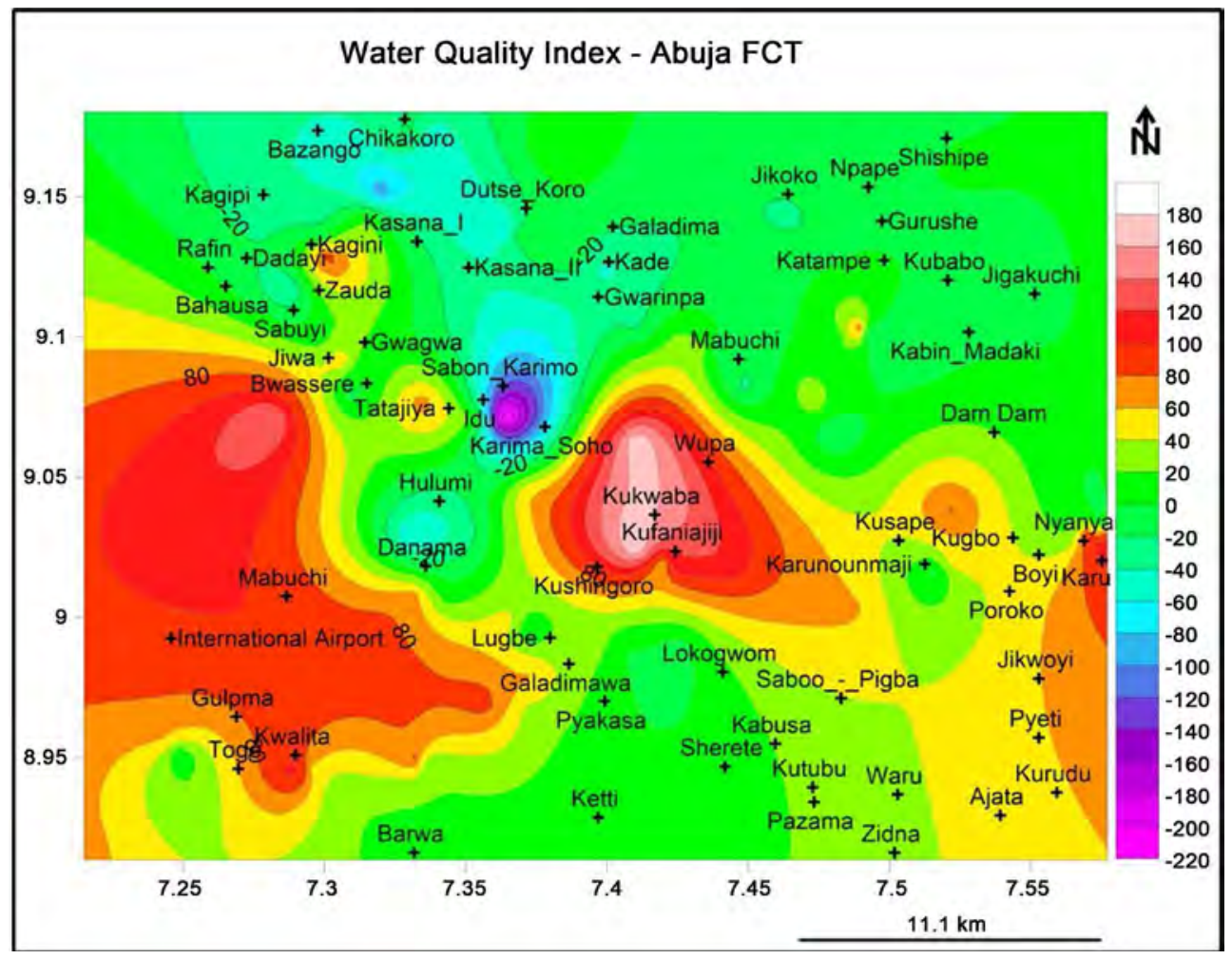

Figure 15. Spatial variation of WQI of groundwater in Abuja; high values are at Nyanya, Karu, Wupa, Kukwaba, Kushingoro, Kwalita, Mabuchi, Gulpma and Kagina whereas low values are at Kanimo.

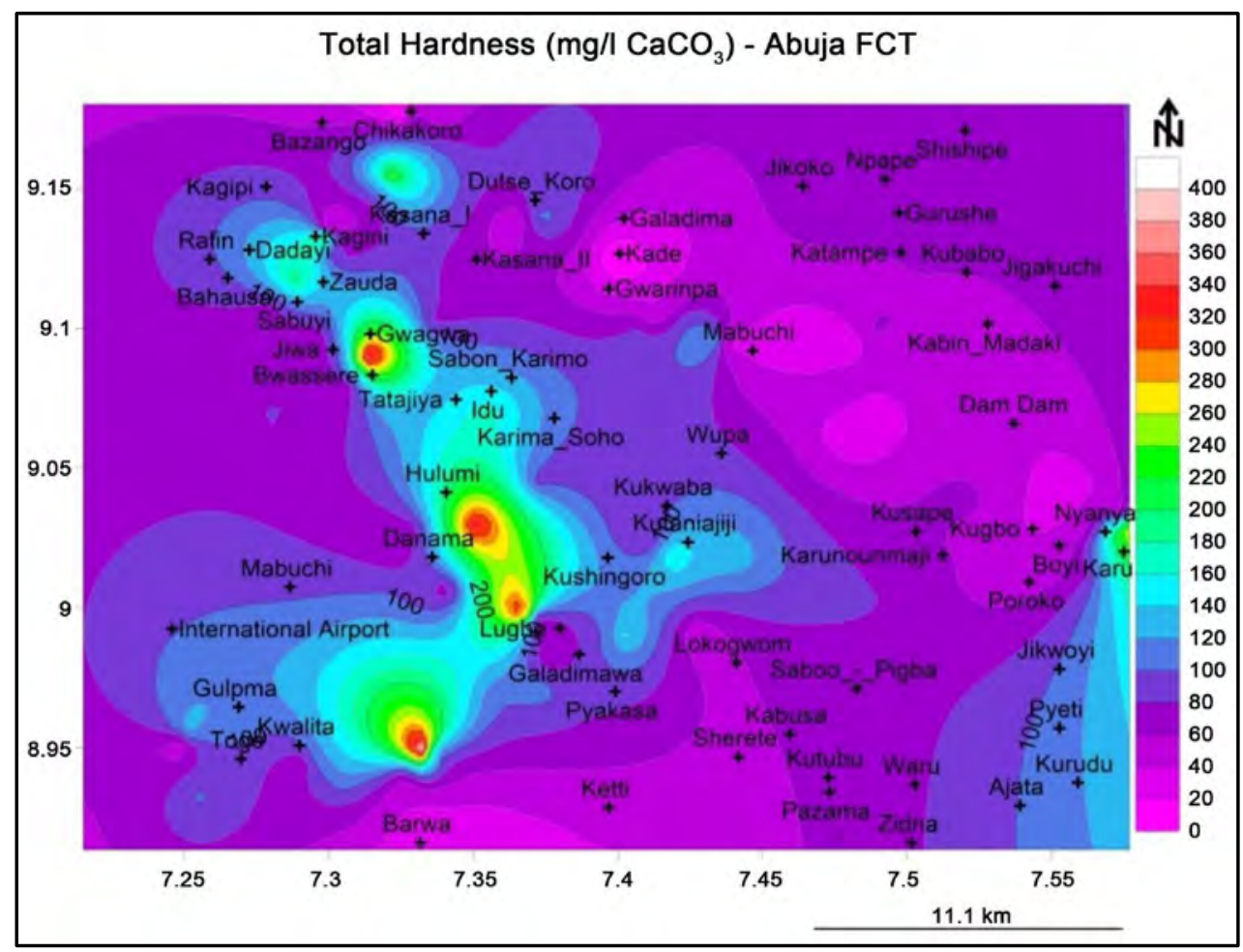

Figure 16. Spatial variation of total hardness: There is a general increase at Gwagwa, Hulumi and Danama. Low values are at Barwa, Mabuchi, Kade, Gwarinpa and Sherete. 
Table 10. Groundwater hardness in Abuja [33].

\begin{tabular}{cccc}
\hline Hardness & Remark on Quality & No of Samples & \% of Samples \\
\hline $0-75$ & Soft & 45 & 47.37 \\
$76-150$ & Moderately Hard & 39 & 41.05 \\
$151-300$ & Hard & 6 & 6.32 \\
$>300$ & Very Hard & 5 & 5.26 \\
\hline
\end{tabular}

\section{Conclusions}

The groundwater in Abuja FCT is acidic to slightly alkaline in nature, soft to moderately hard and of low to high salinity.

Borehole depths range from 19.5 - $34.5 \mathrm{~m}$ with static water levels between 3 12 m.a.m.s.l.

Yields were between $3.2-7.2 \mathrm{~m}^{3} / \mathrm{Hr}$.

Major water types are $\mathrm{MgHCO}_{3}$ and $\mathrm{CaHCO}_{3}$ while the hydrogeochemical facies present are $\mathrm{Ca}-\mathrm{Mg}-\mathrm{Cl}-\mathrm{SO}_{4}, \mathrm{Ca}-\mathrm{Mg}-\mathrm{HCO}_{3}$ and $\mathrm{Na}-\mathrm{Mg}-\mathrm{HCO}_{3}$. Major processes controlling the water quality is the weathering of the host rock through mineral dissolution, cation exchange and inverse cation exchange processes. The chloro-alkaline indices indicated the dominance of alkaline earth elements over alkalis through ion exchange from rock to the groundwater and reverse softening of groundwater by infiltrating rainwater. Water quality index is below the recommended value and groundwater is suitable for domestic purpose. Ion-exchange, simple dissolution and uncommon dissolution processes determined the groundwater character of Abuja FCT.

\section{Conflicts of Interest}

The authors declare no conflicts of interest regarding the publication of this paper.

\section{References}

[1] Todd, D.K. (1980) Groundwater Hydrology. Wiley, New York.

[2] Sakram, G., Sundaraiah, R., Vishnu, B. and Praveen, R.S. (2013). The Impact of Agricultural Activity on the Chemical Quality of Groundwater, Karanjavagu Watershed, Medak District. Andhra Pradesh International Journal of Advanced Scientific and Technical Research, 6, 769-786.

[3] Sajil Kumar, P.J. (2013) Interpretation of Groundwater Chemistry Using Piper and chadhás Diagrams: A Comparative Study from Perambalur Taluk. Elixir Geoscience, 54, 12208-12211.

[4] Akoachere, R.A., Eyong, T.A., Egbe, S.E., Wotany, R.E., Nwude, M.O. and Yaya, O.O. (2019) Geogenic Imprint on Groundwater and Its Quality in Parts of the Mamfe Basin, Manyu Division, Cameroon. Journal of Geoscience and Environment Protection, 7, 184-211. https://doi.org/10.4236/gep.2019.75016

[5] Ajibade, A.C. and Wright, J.B. (1988) Structural Relationship in Schist Belts of Northwestern Nigeria. In: Oluyide, P.O., et al., Eds., Precambrian Geology of Nigeria, Geological Survey of Nigeria, Nigeria, 103-109. 
[6] Omada, J.I. and Obayomi, O.O. (2012) An Assessment of Groundwater Resources in Basement Complex Terrain Ofgwarinpa-Kafe Area of Abuja Metropolis, Central Nigeria. Advances in Applied Science Research, 3, 393-398.

[7] Agunleti, Y.S. and Arikawe, E.A. (2014) Groundwater Targeting Within The Basement Complex Rocks of Federal Capital Territory Abuja Using Remotely Sensed and Vertical Electrical Sounding Data. International Journal of Technology Enhancements and Emerging Engineering Research, 2, 38-47.

[8] Ajibade, A.C. (1976) Proterozoic Crustal Development in the Pan-African Regime of Nigeria. In: Kogbe, C.A., Ed., Geology of Nigeria, Rock View Ltd., Nigeria, 57-63.

[9] Mc-Curry, P. (1985) The Geology of the Precambrian to Lower Paleozoic Rocks of Northern Nigeria: A Review, In: Kogbe, C.A., Ed., Geology of Nigeria, Elizabethan Co., Lagos, 15-39.

[10] Ajibade, A.C. and Woakes, M. (1983) Proterozoic Crustal Development in the Pan-African Regime of Nigeria. In: Kogbe, C.A., Ed., Geology of Nigeria, Rock View Ltd., Nigeria, 57-63.

[11] WRC (1992) Groundwater Sampling Manual. Water Research Commission (WRC). Pretoria, South Africa.

[12] American Public Health Association (APHA) (1985) Standard Methods for Examination of Water and Waste Water. American Public Health Association, American Water Works Association and Water Pollution Control Federation, Washington DC.

[13] Van Tonder, G.J., Botha, J.F., Chiang, W.H., Kunstmann, H. and Xu, Y. (2001) Estimation of the Sustainable Yields of Boreholes in Fractured Rock Formations. Journal of Hydrology, 241, 70-90.

[14] Schoeller, H. (1965) Qualitative Evaluation of Groundwater Resources. In: Methods and Techniques of Groundwater Investigations and Development, UNESCO, Paris, 54-83.

[15] Schoeller, H. (1967) Geochemistry of Groundwater. An International Guide for Research and Practice. UNESCO, Paris, 1-18.

[16] Schoeller, H. (1977) Geochemistry of Groundwater. Groundwater Studies-An International Guide for Research and Practice, Chapter 15. UNESCO, Paris, 1-18.

[17] Hounslow, A.W. (1995) Water Quality Data: Analysis and Interpretation. Lewis Publishers CRC Press, New York, 397.

[18] Langguth, H.R. (1966) Groundwater Verhaltisse in Bereiech Des Velberter. Sattles. Der Minister Fur Eraehrung, Land Wirtsch Forste Duesseldorf, NRW, 127.

[19] Lloyd, J.A. and Heathcote, J.A. (1985) Natural Inorganic Hydrochemistry in Relation to Groundwater: An Introduction. Oxford University Press, New York, 296.

[20] Sisodia, R. and Moundiotiya, C. (2006) Assessment of the Water Quality Index of Wetland Kalakho Lake, Rajasthan. Journal of Environmental Hydrology, 14, 1-11.

[21] Akoachere, R. and Van Tonder, G. (2011) The Trigger-Tube: A New Apparatus and Method for Mixing Solutes for Injection Tests in Boreholes. Water SA, 37, 139-146.

[22] O’Brien, P.J. (1970) Aquifer Transmissivity Distribution as Reflected by Overlying Soil Temperature Pattern. Ph.D. Dissertation, Pennsylvania State University, Pennsylvania, PA.

[23] Bair, E.S. and Parizek, R.R. (1979) Detection of Permeability Variations by a Shallow Geothermal Technique. Ground Water, 16, 254-263. https://doi.org/10.1111/j.1745-6584.1978.tb03233.x

[24] Gibbs, R.J. (1970) Mechanisms Controlling World's Water Chemistry. Science, 170, 
1088-1090. https://doi.org/10.1126/science.170.3962.1088

[25] Akoachere, R.A., Yaya, O.O., Egbe, S.E., Eyong, T.A., Nji, B.N. and Tambe, D.B. (2019) GIS-Hydrogeochemical Model of the Yaoundé Fractured Rock Aquifer, Cameroon: Aquifer Setting, Seasonal Variations in Groundwater-Rock Interaction and Water Quality. Journal of Geoscience and Environment Protection, 7, 232-263. https://doi.org/10.4236/gep.2019.75018

[26] Wyns, R.J.M., Lachassagne, P., Baltassat, J.M., Vairo, J., Legchenko, A. and Mathieu, F. (2004) Application of SNMR Soundings for Groundwater Reserves Mapping in Weathered Basement Rocks (Brittany France). Bulletin of the Geology Society of France, 175, 21-34. https://doi.org/10.2113/175.1.21

[27] Dewandel, B., Lachassagne, P., Marechal, J.C., Wyns, R. and Krishnamurthy, N.S. (2006) A Generalized 3-D Geological and Hydrogeological Conceptual Model of Granite Aquifers Controlled by Single or Multiphase Weathering. Journal of $\mathrm{Hy}$ drology, 330, 260-284. https://doi.org/10.1016/j.jhydrol.2006.03.026

[28] Hem, J.D. (1985) Study and Interpretation of the Chemical Characteristics of Natural Water. 3rd Edition, US Geological Survey Water-Supply Paper, University of Virginia, Charlottesville, VA, $263 \mathrm{p}$.

[29] Piper, A.M. (1944) A Geographic Procedure in the Geochemical Interpretation of Water Analysis. Transactions American Geophysical Union, 25, 914-923. https://doi.org/10.1029/TR025i006p00914

[30] Durov, S.A. (1948) Classification of Natural Waters and Graphical Representation of Their Composition. Doklady Akademii Nauk SSSR, 59, 87-90.

[31] World Health Organization (2017) Guidelines for Drinking-Water Quality. 4th Edition, Incorporating the First Addendum, Geneva.

[32] Asadi, J.J., Vuppala, P. and Reddy, M.A. (2007) Remote Sensing and GIS Techniques for Evaluation of Groundwater Quality in Municipal Corporation of Hyderabad (Zone-V), India. International Journal of Environmental Research and Public Health, 4, 45-52. https://doi.org/10.3390/ijerph2007010008

[33] Sawyer, C.N. and McCarty, P.L. (1967) Chemistry for Sanitary Engineers. 2nd Edition, McGraw Hill, New York, 518. 